\title{
Chemical Reviews
}

Volume 94, Number $2 \quad$ March/April 1994

\section{Metallomacrocycles: Supramolecular Chemistry with Hard and Soft Metal Cations in Action}

\author{
Frank C. J. M. van Veggel, Willem Verboom, and David N. Reinhoudt" \\ Laboratory of Organic Chemistry, University of Twente, P.O. Box 217, 7500 AE Enschede, The Netherlands
}

Recelved April 12, 1993 (Revised Manuscript Received September 16, 1993)

\section{Contents}

I. Introduction

II. Hetero-dinuclear and Hetero-trinuclear Complexes with Bridging Ligands between the Different Metal Cations

III. Crown Ether-Substituted Phthalocyanines, Porphyrins, and Related Structures
A. Phthalocyanines
B. Porphyrins
C. Related Structures

IV. Activation of Carbon Monoxide

V. Bipyridine- and Phenanthroline-Containing Ligands

VI. Ferrocenophanes and Ruthenocenophanes

VII. Miscellaneous

VIII. Summary

IX. References

\section{Introduction}

Since the early work of Pedersen, ${ }^{1} \mathrm{Cram},{ }^{2}$ and $\mathrm{Lehn}^{3}$ the field of "supramolecular chemistry" or "host-guest chemistry" has grown enormously. "Supramolecular chemistry can be defined as the chemistry beyond the covalent bond or the chemistry of associates with a well-defined structure. ${ }^{3}$ The structures of the associates are governed by relatively weak forces such as hydrogen bonds, ion-dipole and dipole-dipole interactions, van der Waals interactions, etc. Most of the work has concentrated on the design of selective receptors for either alkaline and alkaline earth cations. ${ }^{5}$ These cations are referred to as "hard" which means that they have a low polarizability. Transition metal cations are defined as "soft", because they are relatively easy to polarize. ${ }^{6}$ Among the many applications of selective complexation of cations are chemical sensors, ${ }^{7}$ the selective removal of poisonous or radioactive metal cations from waste streams, ${ }^{8}$ membrane transport, ${ }^{9}$ immobilization of radioisotopes, ${ }^{10}$ and as phase-transfer catalysts. ${ }^{11}$

Recently also host molecules have been designed in which one or more metal cations are incorporated to allow the selective binding of anions ${ }^{12}$ and nucleophilic groups of neutral molecules that can coordinate to the metal cations. ${ }^{13,14}$ Other areas of interest are model systems for (metallo)enzymes ${ }^{15}$ and the activation of small molecules like $\mathrm{O}_{2},{ }^{16} \mathrm{CO}$ (vide infra), $\mathrm{CO}_{2},{ }^{17}$ and $\mathrm{N}_{2}{ }^{18}$ Generally organic multidentate ligands are designed in which one or more metal cations are complexed at well-defined positions. The field of homo- and hetero-dinuclear complexes of two transition metal cations has received considerable attention in order to achieve the above mentioned goals, which are often strongly related. ${ }^{19}$ Most of the work in this area has focused on model systems for hemocyanin and tyrosinase, both possessing two copper cations in the active site. ${ }^{16}$

The present review exclusively deals with metallomacrocycles which contain combinations of hard and soft metal cations. Metallomacrocycles are defined as metal complexes which are able to co-complex another metal cation. Many studies aim for the modulation of the redox properties of a complexed transition metal cation upon the co-complexation of a hard cation. The influence of co-complexation is not limited to complexed transition metal cations, also organic moieties that are redox active have been incorporated in ligands that can complex hard cations. ${ }^{20}$ Other areas of interest are allosteric effects, supramolecular aggregates, and bimetallic activation and catalysis.

In the first part hetero-di- and hetero-trinuclear complexes with bridging ligands between hard and soft cations are discussed. The second section deals with phthalocyanines, porphyrins, and related structures, followed by the activation of carbon monoxide in heterodinuclear complexes. Bipyridine- and phenanthrolinecontaining crown ethers and ferrocenophanes and ruthenocenophanes will be discussed separately. The 


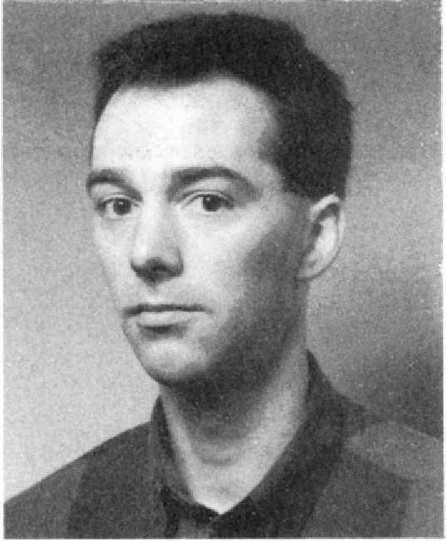

Dr.ir. Frank C. J. M. van Veggel (1963) studied Chemical Technology at the University of Twente (The Netherlands) where he graduated in 1986 with Prof.dr.ir. D. N. Reinhoudt on the synthesis of mitomycin $\mathrm{C}$ analogs for the treatment of tumors. In the same group he did his Ph.D. (suma cum laude) on a thesis entitled: Metallomacrocycles: Synthesis, X-ray Structure, Electrochemistry, and ESR spectroscopy. He then joined the photonics research group of the Dutch chemical company Akzo, where he performed research on nonlinear optical materials and optical amplification. In August 1992 he returned to the academia and is currently doing research in the group of Prof.dr.ir. D. N. Reinhoudt. At present his major interests are in the field of nonlinear optical materials, optical amplification, hetero-di- and hetero-multinuclear complexes for electrocatalysis and computational chemistry. $\mathrm{He}$ is the author of 20 scientific papers and review articles and two patents.

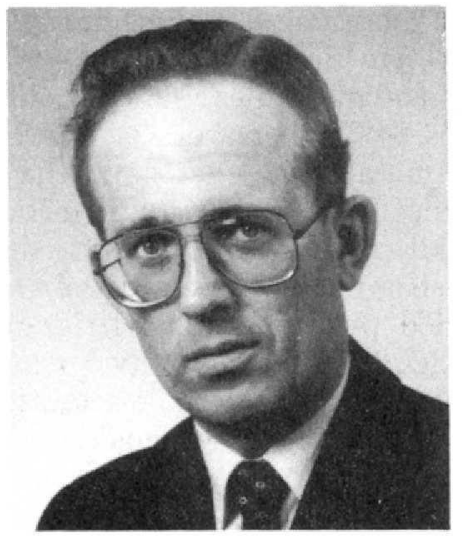

Dr. Willem Verboom (1954) studied chemistry at the State University of Utrecht (The Netherlands) were he graduated in 1980 with Prof.dr. H. J. T. Bos on a thesis entitled: Thermal and photochemical rearrangements of $\gamma$-oxo- $\alpha, \beta$-unsaturated carboxamides and esters. In 1980 he joined the Laboratory of Organic Chemistry at the University of Twente where he is a senior staff member of Prof.dr.ir. D. N. Reinhoudt. At first he was involved in heterocyclic chemistry (tert-amino effect, mitomycins, etc.). At present his major research interest deals with supramolecular chemistry (synthesis of calixarenes, resorcinarenes, (metallo)macrocycles, metalloclefts, etc., and complexation studies with anions, cations, and neutral guest molecules). $\mathrm{He}$ is author of more than 135 scientific papers and review articles and three patents.

last section contains miscellaneous ligands in which hard and soft metal cations are combined. The literature cited covers the period to the end of 1992.

\section{Hetero-dinuclear and Hetero-trinuclear Complexes with Bridging Ligands between the Different Metal Cations}

Only recently have ligands capable of positioning two or more very different metal cations, like transition

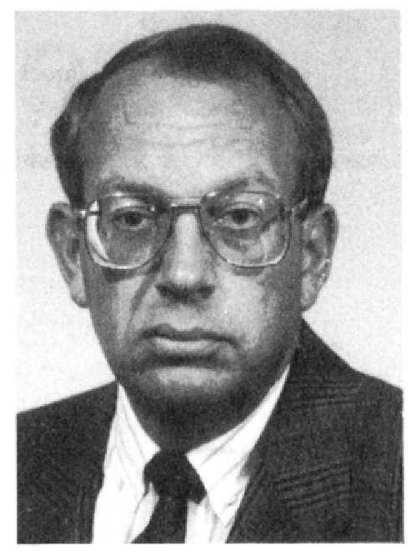

Professor David N. Reinhoudt was born in 1942 in the Netherlands. He studied Chemical Technology at the Delft University of Technology and graduated (suma cum laude) in chemistry in 1969 with Professor $\mathrm{H}$. C. Beijerman on a thesis entitled: On the synthesis of Cephalosporin C. In 1970 he joined the Royal Dutch/Shell Laboratories in Amsterdam as a research chemist in the department of Organic Chemistry. In 1971 he started the crown ether research program at Shell; he also worked on the physical organic chemistry of crown ether complexation. In 1975 he was appointed as a part-time professor (extraordinarius) at Twente University followed by the appointment as a full professor in 1978. The major part of his research deals with supramolecular chemistry, e.g. the synthesis of crown ethers, calixarenes, and (hemi)spherands, complexation studies with neutral guest molecules, and the application of supramolecular chemistry in membrane transport, in the field of electronic or optical sensor systems, catalysis, and molecular (NLO) materials. He is the author of more than 320 scientific publications, patents, and review articles and has written a book on the chemistry of macrocycles.

metal and alkali or alkaline earth metal cations, in close proximity been described. A general approach to bringing two metal cations close together (intermetallic distance $<4 \AA$ ) is the use of a bridging ligand, ${ }^{19}$ which is also followed here to achieve the above mentioned goal. Ligands for the complexation of two different metal cations should possess cavities of different nature, such as tetradentate ligands for transition metal cations and crown ether type cavities for hard cations like alkali or alkaline earth metal cations.

Reinhoudt et al. have started an intensive program and synthesized a number of ligands and the corresponding complexes in which both the cavity for transition metal cations as well as the cavity for the alkali or alkaline earth metal cations are systematically varied. ${ }^{13 b, 21-27}$ It was anticipated that co-complexation of a hard cation close to the complexed transition metal cation would change its (redox) properties. The complexes were studied by X-ray crystallography, polarography, cyclic voltammetry, coulometry, and EPR spectroscopy. The ultimate goal is to realize bimetallic (electro)catalysis with well-defined complexes.

The synthesis of complexes 1-5 (Chart 1) is schematically depicted in Scheme 1. The cyclization of a diamine and a dialdehyde was carried out by high dilution techniques in the presence of a barium salt, acting as a template. In case of an aromatic diamine the resulting barium complexes 1 and 2 could be isolated as orange to red crystalline materials in $53-82 \%$ yield. $\mathrm{X}$-ray analysis of a number of barium complexes showed the barium cation complexed to the polyether cavity. In the case of an aliphatic diamine the resulting barium complex was not isolated but reacted in situ with nickel or copper acetate to give the dinuclear complexes 3 and 


\section{Chart 1}

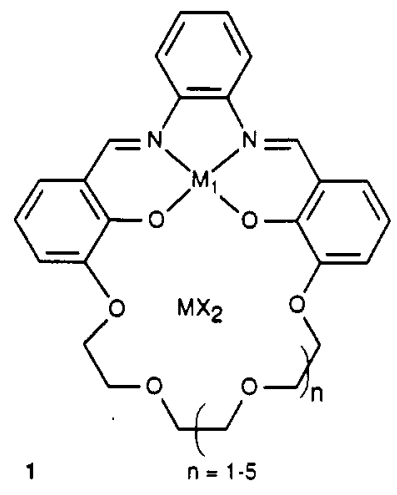<smiles></smiles><smiles>Oc1c2cccc(ccn1O)[N+]1(N(O)C=Cc3ccccc3OCCOCCc3ccccc3)Oc3cccc(c3O1)OCCOCCO2</smiles>

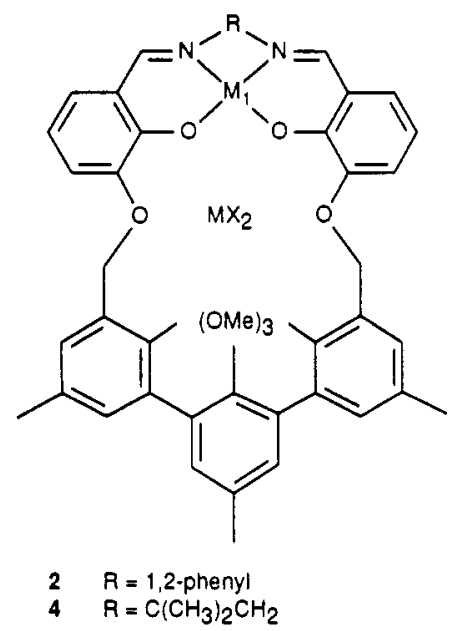

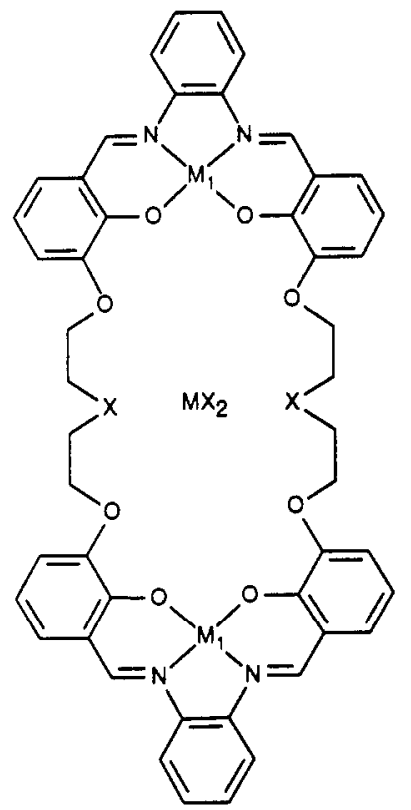

$6 \quad \mathrm{M}_{1}=2 \mathrm{H}, \mathrm{Ni}, \mathrm{Cu}$ $M X_{2}=\underset{\mathrm{Cs}\left(\mathrm{CF}_{3} \mathrm{SO}_{3}\right)_{2}}{\mathrm{Cs}\left(\mathrm{CF}_{3} \mathrm{SO}_{3}\right)}$ $X=0,5$

\section{Scheme 1}
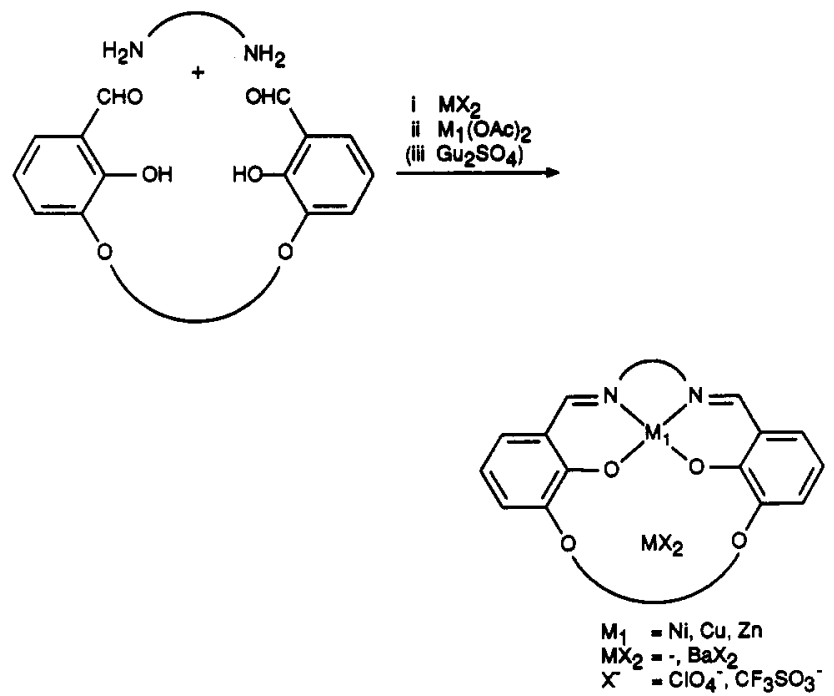

4 as crystalline, strongly colored materials in $71-85 \%$ yield. A number of X-ray analyses have been carried out and revealed the phenolate anion as bridging ligand between the two different metal cations (an example is given in Figure 1).

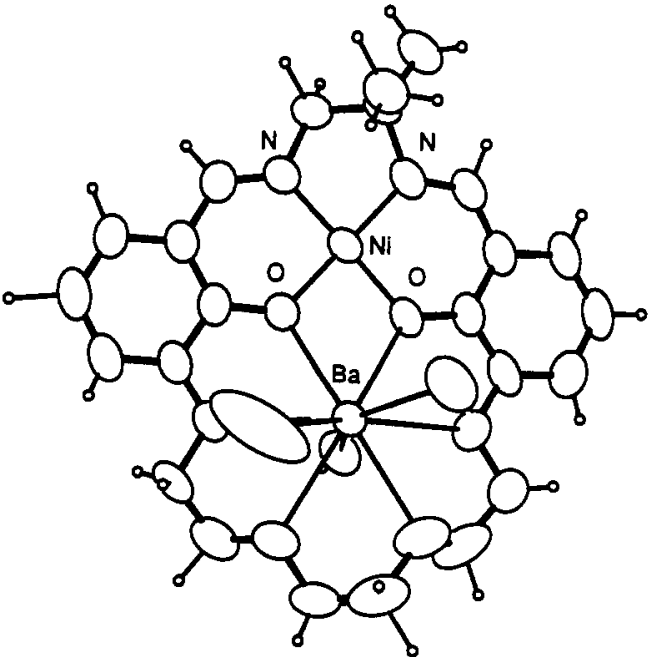

Figure 1. X-ray structure of the nickel/barium complex $3 \cdot \mathrm{H}_{2} \mathrm{O}(n=1)$. Only the oxygen atoms of the triflate anions are shown for clarity. (Reprinted from ref 23. Copyright 1989 American Chemical Society.)

Intermetallic distances are in the range of 3.63-3.69 $\AA$. The nickel and copper complexes have square planar coordination as can be expected for salen- and salo- 
phen-type tetradentate ligands. ${ }^{28}$ In the case of zinc a square pyrimidal coordination was found with the salophen unit forming the ground plane and a DMF molecule at the apical position. The hard cation interacts with all oxygens of the polyether cavity and the coordination sphere is completed by counteranions and/or solvent molecules. In an analogous way the dinuclear complexes 5 with two (alkylated) oxime bonds were synthesized in 55-82\% yield. X-ray analyses of a number of complexes showed the intermetallic distances were in the range of $3.69-3.73 \AA$. It was expected that the electron-donating properties of the nitrogen atoms would be changed by the oxygen substituent and hence the (redox) properties of the complexes.

The consequence of co-complexation of a hard cation to the transition metal complexes is an anodic shift of the reduction potential. Anodic shifts up to $300 \mathrm{mV}$ were observed upon co-complexation of $\mathrm{Ba}^{2+}$. Smaller shifts (about $50 \mathrm{mV}$ ) were observed for the monovalent cations. Hard cations $\left(\mathrm{Ba}^{2+}, \mathrm{K}^{+}, \mathrm{Na}^{+}\right.$, and $\mathrm{Li}^{+}$) complexed in the polyether cavity reduce the electron density at the phenolic oxygen atoms, and this lowers the electron-donating ability toward the transition metal ion. Consequently the transition metal ion is more positively charged, and therefore the reduction will occur at a less negative potential. The complexes of (alkylated) oximes 5 are reduced at less cathodic potentials than the complexes 3 . The oxygen atom reduces the electron-donating properties of the nitrogen atom which renders the complexed transition metal cation more positively charged, and this leads to a reduction at a less negative potential. Cyclic voltammetry showed that the reduction-oxidation process is in general both electrochemically and chemically reversible. The latter observation is important for electrocatalysis, because the electrocatalyst should be stable after electrochemical reduction (activation) before reacting with a substrate. The association constants of the $\mathrm{Li}^{+}$complexes are smaller than those of the complexes with the other hard cations $\left[K_{\text {assoc }}\right.$ $\left(\mathrm{Na}^{+}, \mathrm{K}^{+}\right.$, or $\left.\mathrm{Ba}^{2+}\right)>10^{6} \mathrm{~L} \mathrm{~mol}^{-1}$ in DMSO].

The first example of electrocatalysis by a dinuclear complex is the conversion of benzyl bromide into phenylacetone in the presence of the nickel/barium complex 3 and acetic anhydride. This transformation does not occur in the presence of the corresponding nickel complex 3 in which case only toluene and bibenzyl are formed. ${ }^{25}$ The reaction of the nickel/barium complex 3, benzyl bromide, and two electrons leads to an intermediate with a (relatively) stable nickel-carbon bond.

When the reaction depicted in Scheme 1 was performed with a dialdehyde that has a shorter chain between the two phenyl rings, a [2+2] instead of a [1 +1 ] macrocyclization occurred. This results in a macrocycle with three compartments for complexation of metal cations. ${ }^{26,27}$ The barium and cesium complexes 6 were obtained as orange crystalline compounds in 45-69\% yield. According to the X-ray analysis of the barium complex 6 the barium is coordinated to all 10 of the oxygen atoms of the macrocycle, and this causes a folding of the macrocycle around barium. Consequently the two nearly planar salophen units are approximately parallel to each other. These barium

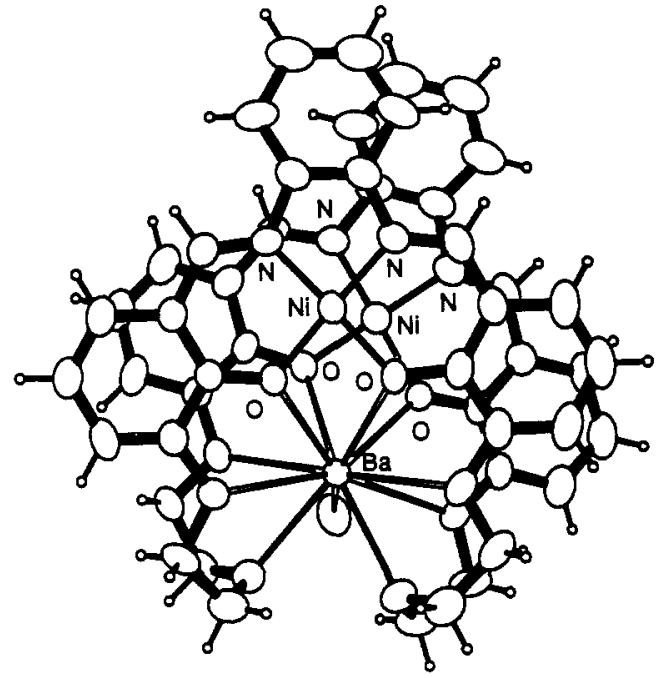

Figure 2. X-ray structure of the dinickel/barium complex 6. $\mathrm{H}_{2} \mathrm{O}(\mathrm{X}=\mathrm{O})$. (Reprinted from ref 27 . Copyright 1991 American Chemical Society.)

and cesium complexes could be readily converted into their trinuclear complexes by reaction with 2 equiv of nickel or copper acetate. The dinickel/barium complex 6 (Figure 2) and the dicopper/barium complex 6 were analyzed by X-ray crystallography. The most interesting feature is the short intermetallic distance between the two transition metal cations $\left[\mathrm{Ni}^{2+}-\mathrm{Ni}^{2+}=3.42 \AA\right.$ and $\mathrm{Cu}^{2+}-\mathrm{Cu}^{2+}=3.50 \AA$ ] without a bridging ligand. This very short distance results from the coordination of $\mathrm{Ba}^{2+}$ to the polyether cavity.

Polarography and cyclic voltammetry of the coppercontaining trinuclear complexes clearly showed that the reduction process proceeds in two distinct oneelectron steps. After the first one-electron reduction the redox properties of the other complexed transition metal cation is changed. This evidence suggests that the conformation of the complex in solution is similar to the conformation in the solid state.

EPR spectroscopy of the copper-containing complexes $6\left(\mathrm{MX}_{2}=\mathrm{Ba}\left(\mathrm{CF}_{3} \mathrm{SO}_{3}\right)_{2} ; \mathrm{X}=\mathrm{O}\right.$ and $\left.\mathrm{S}\right)$ exhibits typical signals for an $S=1$ system, which means that the copper cations are ferromagnetically coupled. From the spectra a $\mathrm{Cu}-\mathrm{Cu}$ distance of $3.6 \AA$ could be deduced, which is in reasonable agreement with the distance in the solid state. These measurements also support a folded structure with a cofacial alignment of the two salophen units.

Sessler et al. ${ }^{29}$ have reported the copper complex 7 (Chart 2) which potentially has a cavity for hard cations. Attempts to bind $\mathrm{Na}^{+}$have met with little success which can be explained by the fact that one of the oxygen atoms $\beta$ to a nitrogen atom is coordinated to the copper cation, as was observed in the X-ray structure of 7 . This coordination might render the remaining cavity too small for co-complexation of a second cation (Figure 3).

Hetero-dinuclear complexes 8 (Chart 2) with two thiolate anions bridging the two different metal cations have been reported by Becher et al. ${ }^{30}$ They have used the same method as depicted in Scheme 1. Both $\mathrm{Ba}^{2+}$ and $\mathrm{Tl}^{+}$have been used as the hard cation.

Schepartz and McDevitt ${ }^{31}$ have reported the "selfassembly" of the ionophores 9 (Chart 2) by complexation of nickel(II) to two bidentate salicylaldimines. The 


\section{Chart 2}
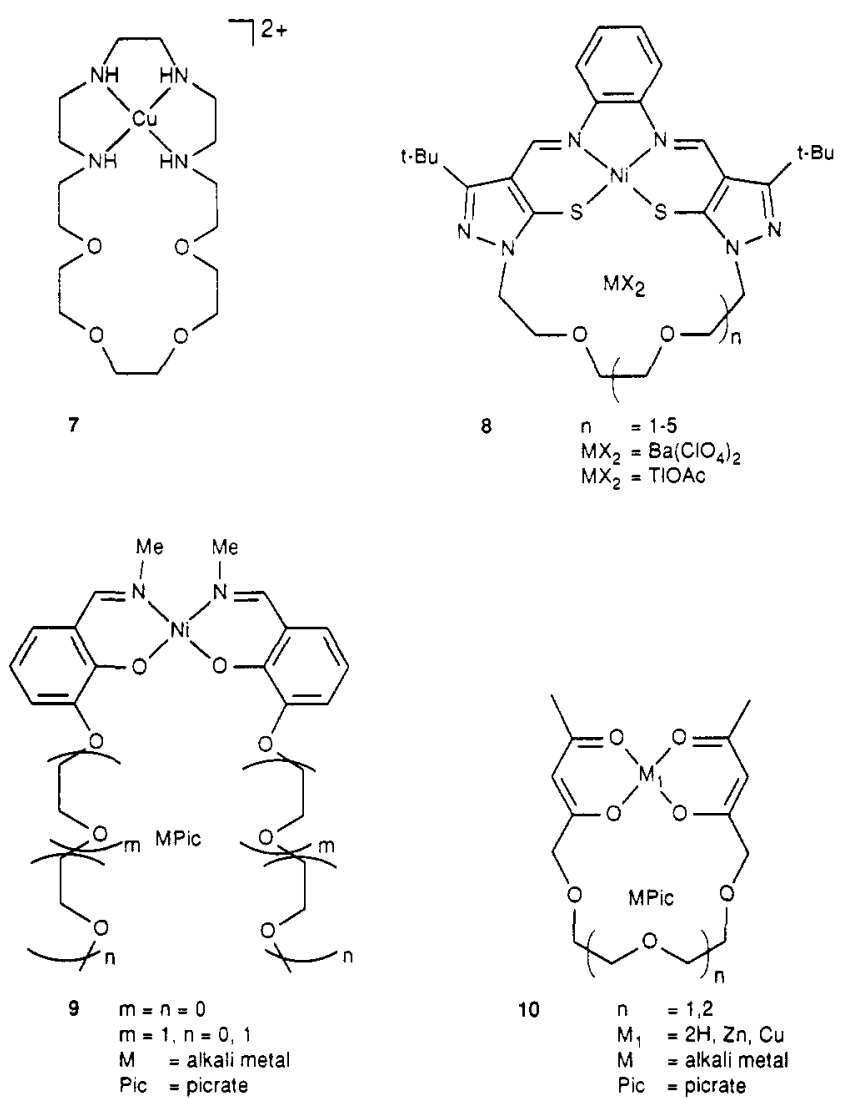

result of this complexation is the formation of a podandtype receptor for alkali cations. In their report no information about the structure of the nickel complexes was given which can be square planar (syn or anti) or tetrahedral. ${ }^{32}$ Gokel et al. ${ }^{33}$ showed that in toluene solution these complexes have a square planar geometry. It remained unclear whether a syn or anti coordination was obtained, but without complexation of a hard cation in the podand the ant $i$ stereochemistry is most likely. ${ }^{34}$ An X-ray analysis of the nickel/sodium picrate complex $9(m=n=0)$ was reported showing discrete dimers with coordinated picrate anion and one water molecule as integral parts (Figure 4). The nickel cations have an octahedral instead of square planar coordination as was also found in solutions of $\mathrm{MeOH}$ and $\mathrm{CHCl}_{3}$.

Extraction experiments of alkali metal picrate salts from an aqueous phase into a chloroform phase containing the nickel complexes showed moderate to good efficiencies. Vapor pressure osmometry showed that the nickel complex $9(m=1, n=0)$ in $0.1 \mathrm{M} \mathrm{NaClO}_{4}$ solution in acetone are present as discrete $\mathrm{Na}_{2} \mathrm{Ni}_{2}$ complexes. ${ }^{35}$ In contrast to the more anodic reduction of the complexes 1-4 the $\mathrm{Na}_{2} \mathrm{Ni}_{2}$ complexes are reduced at more cathodic potentials than the corresponding nickel complexes. Since "self-assembly" is defined as the spontaneous formation of higher order structures, i.e. self-assembled monolayers, ${ }^{36}$ the above mentioned results are more appropriately described in terms of an allosteric effect. It is, however, most likely that upon co-complexation of a hard cation a conformational reorganization around the complexed nickel cation occurs.

Kobule and Satoh ${ }^{37}$ have reported the synthesis of copper and zinc complexes of polyether bis ( $\beta$-diketone) ligands (10, Chart 2) in $90 \%$ yield resulting in the

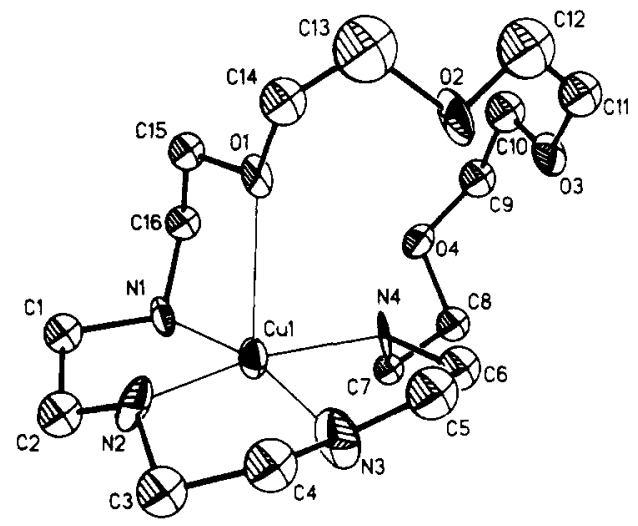

Figure 3. X-ray structure of the copper complex 7. (Reprinted from ref 29. Copyright 1989 American Chemical Society.)

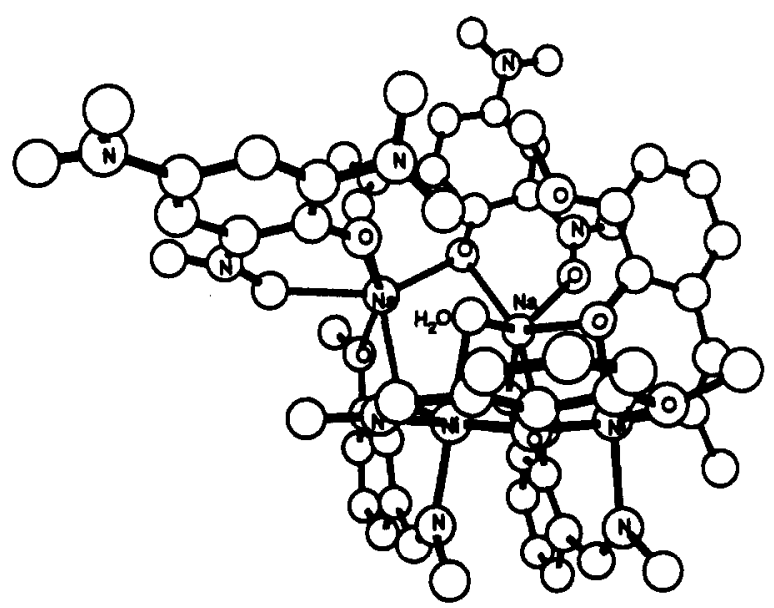

Figure 4. X-ray structure of the nickel/sodium picrate complex $9(m=n=0)$. (Reprinted from ref 33 . Copyright 1991 American Chemical Society.)

formation of a polyether cavity for hard cations. They showed that the ligands by themself are not able to extract alkali cations from an aqueous solution into chloroform. Reaction of the bis( $\beta$-diketone) ligands with copper(II) and zinc(II) leads to cyclic receptors for hard cations. The copper complex $10(n=1)$ has a selectivity for $\mathrm{Na}^{+}$over the other alkali cations, whereas the copper complex $10(n=2)$ has a selectivity for $\mathrm{K}^{+}$and $\mathrm{Rb}^{+}$over $\mathrm{Li}^{+}$and $\mathrm{Na}^{+}$. The complexation of copper or zinc is a good example of an allosteric effect.

\section{Crown Ether-Substifuted Phthalocyanines, Porphyrins, and Related Structures}

Complexation of alkali and alkaline earth metal cations to phthalocyanines, porphyrins, and related square planar tetradentate ligands with covalently attached crown ethers may lead to ordered supramolecular structures that exhibit interesting optical, electrical, and electrochemical properties.

\section{A. Phthalocyanines}

Nolte and co-workers ${ }^{38-42}$ have studied the electrical properties of the crowned phthalocyanines $11 b-d$ (Chart 3 ) by performing impedance measurements as a function of co-complexation of alkaline and alkaline earth metal cations. The free ligand 11a $(n=0-2)$ was synthesized in three steps starting from the appropriate benzocrown ethers in an overall yield of $12 \%$. They observed that, by matching the size of the alkali metal 


\section{Chart 3}

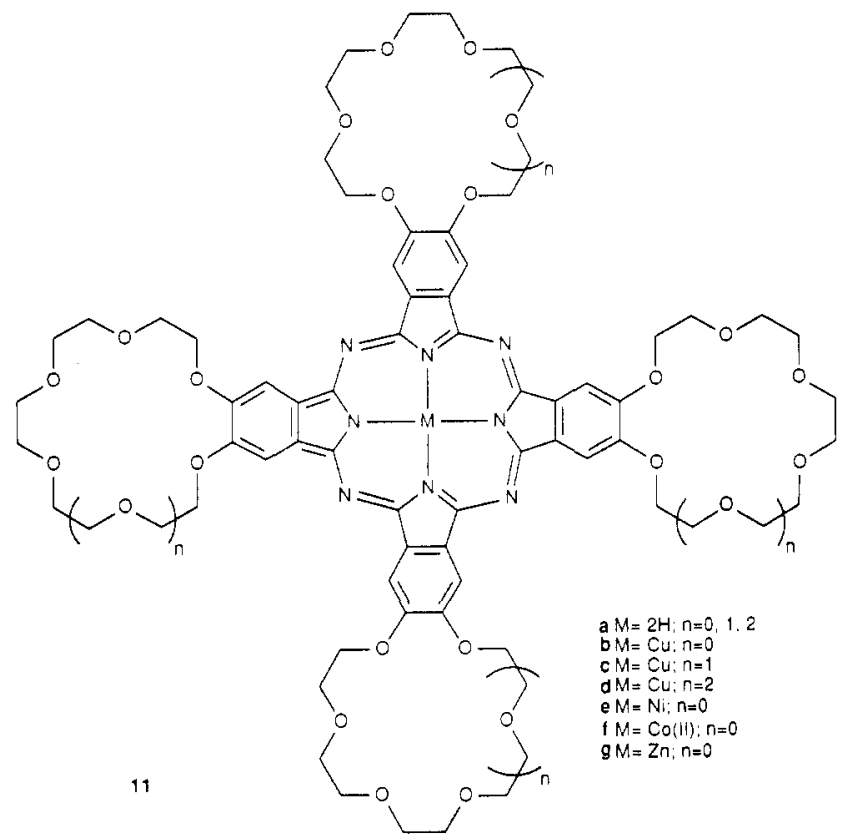

cations and the cavity of the crown ethers, complexes with a 1:1 stoichiometry ( $\mathrm{M}^{n+}$ to crown ether) were obtained. Larger alkali metal cations yielded complexes with a 1:2 $\left(\mathrm{M}^{n+}\right.$ to crown ether) stoichiometry. The 21-crown-7 rings always showed an $\mathrm{M}^{n+}$ to crown ether ratio of 1:1. These results are in agreement with those observed for "simple" crown ethers. ${ }^{43}$ With $\mathrm{K}^{+}, \mathrm{Rb}^{+}$, and $\mathrm{Cs}^{+}$cofacially ordered supramolecular stacks were obtained with very different electrical properties compared to those of the crowned copper-phthalocyanines. The electrical conductivities $\sigma\left(180^{\circ} \mathrm{C} ; \times 10^{7} \mathrm{~S} \mathrm{~m}^{-1}\right)$ are
$11 \mathrm{c}=5$ (p-type); $11 \mathrm{c} \cdot \mathrm{K}^{+}=100$ (n-type); $11 \mathrm{c} \cdot \mathrm{Rb}^{+}=$ 3000 (n-type); $11 \mathbf{c} \cdot \mathrm{Cs}^{+}=700$ (n-type). The co-complexation of $\mathrm{Ba}^{2+}$ to $11 \mathrm{c}$ leads to phthalocyanine networks with a much lower electrical conductivity $\sigma$ of $10^{-6} \mathrm{~S} \mathrm{~m}^{-1}\left(200^{\circ} \mathrm{C}\right)$. A similar value was obtained for $11 \mathrm{~b} \cdot \mathrm{Ba}^{2+}$.

UV-vis absorption and magnetic circular dichroism studies in chloroform/methanol mixtures of the "crowned-5" copper(II), nickel(II), zinc(II), cobalt(II), and free base phthalocyanines have been performed by Stillman and co-workers. ${ }^{44}$ Addition of excess potassium acetate leads to cofacially ordered dimerization. Upon dimerization the spectrum is blue-shifted which is associated with broader and decreased intensities. For the free base the Q-bands ( $\pi-\pi^{*}$ transition) at 660 and $700 \mathrm{~nm}$ shift to $640 \mathrm{~nm}$ (with shoulder) upon dimerization. The blue-shift is far less pronounced in the UV region. In the case of the copper(II), zinc(II), nickel(II), and cobalt(II) phthalocyanines the Q-band located at 670-680 nm shifts upon dimerization to 630 $635 \mathrm{~nm}$. Similar observations have been reported by Kobayashi and Nishiyama, ${ }^{45}$ by Kobayashi and Lever, ${ }^{46}$ and by Bekâroğlu and co-workers. ${ }^{47,48}$ On the basis of EPR spectroscopy using zero field splitting parameters a $\mathrm{Cu}-\mathrm{Cu}$ distance of $4.1 \AA$ could be deduced for $11 \mathrm{~b}$ upon dimerization. In their studies Kobayashi and Lever ${ }^{46}$ showed that the cofacial dimer formation is a three-stage process. Dimerization occurs already with a $\mathrm{K}^{+}$to phthalocyanine ratio of $1: 2\left(K_{\text {assoc }} \approx 6 \times 10^{9} \mathrm{~L}^{2}\right.$ $\mathrm{mol}^{-2}$ in $\mathrm{CHCl}_{3}$ ). The first step occurs with $0-0.5 \mathrm{~K}^{+} /$ $\mathrm{Pc}$; the second step with $0.5-1.5 \mathrm{~K}^{+} / \mathrm{Pc}$; and the third step with $>1.5 \mathrm{~K}+\mathrm{Pc}$. Bekâroğlu and co-workers ${ }^{49}$ have studied the crown- 5 free base 11a $(n=0)$ and copper complex $11 \mathrm{~b}$ with small-angle X-ray diffraction, and

\section{Chart 4}

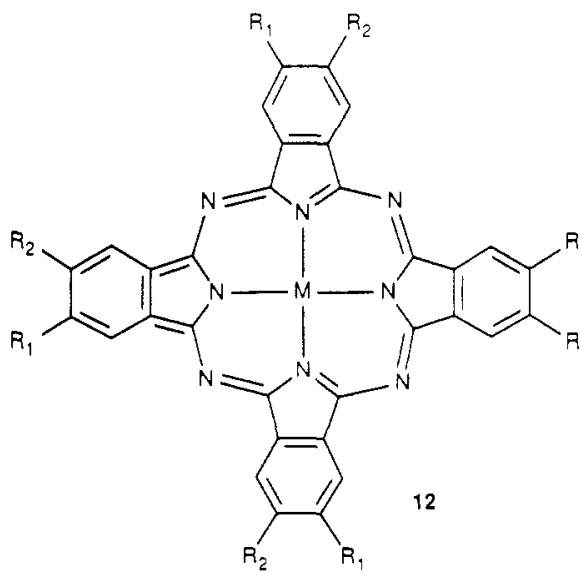<smiles>COc1ccc2c(c1)OCCCCCOCCOCCO2</smiles><smiles>COc1ccc2c(c1)OCCOCCOCCOCCO2</smiles>

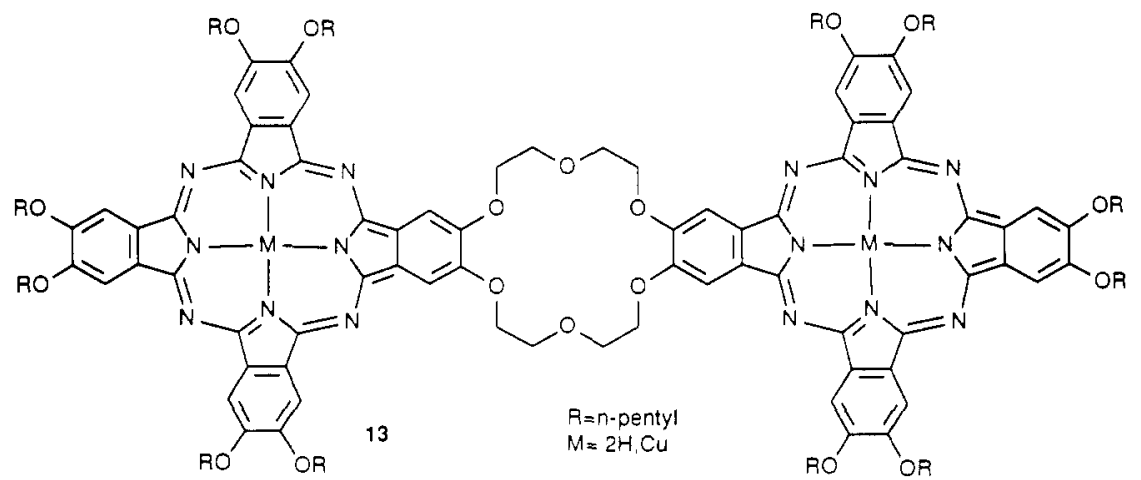


they found that the phthalocyanines are ordered in eclipsed stacks, which may provide an ion channel. Besides this stable crystalline form a meta-stable form with staggered stacks was also found. The crowned phthalocyanines are packed in a zigzag conformation with the crown ether rings parallel to each other and an angle between the crown ether ring and the phthalocyanine moiety of $30^{\circ}$. This packing results in a crown ether to crown ether distance of $4.2 \AA$ and a separation of the phthalocyanine moieties by $3.4-3.5$ $\AA$. This distance is in good agreement with the van der Waals distance of $3.4 \AA$.

Insoluble polymer networks based on crown-6 phthalocyanines have been reported and their alkaline cation binding properties have been studied by solid/ solution extraction experiments. ${ }^{50-52}$ The cobalt(II) derivatives show a large selectivity for $\mathrm{Rb}^{+}$but unfortunately no explanation was given. However, it does not seem likely that binding properties of the crown- 6 moieties are very different from one transition metal to the other. It is therefore possible that the observed selectivity is due to the specific structure of the polymer.

Phthalocyanines with benzo-15-crown-5 ethers attached via flexible spacers (12a and $b$, Chart 4) have been studied by Bekâroğlu and co-workers. ${ }^{53,54} \mathrm{Co}$ complexation of $\mathrm{K}^{+}$to the crowned phthalocyanine $12 \mathrm{a}$ does not lead to dimerization but to intramolecular sandwiching of the cation by the benzo-15-crown-5 rings. Upon co-complexation of $\mathrm{K}^{+}, \mathrm{Na}^{+}$, and $\mathrm{Li}^{+}$no observable changes of the UV-vis spectrum occurred. This is in contrast to the blue-shifts observed for the crowned phthalocyanines discussed above, but consistent with the fact that sandwiching of $\mathrm{K}^{+}$does not lead to phthalocyanine dimers. If only four instead of eight benzo-15-crown-5 moieties are present (12b) dimerization occurs upon co-complexation of $\mathrm{K}^{+}, \mathrm{Rb}^{+}$, and $\mathrm{Cs}^{+}$. The absorption at $670 \mathrm{~nm}$ of the monomer decreases in intensity, whereas the intensity of the absorption at $640 \mathrm{~nm}$ of the dimer increases. Liquidliquid extraction experiments of the free base, the nickel complex, and copper complex show selectivity of $\mathrm{K}^{+}$ and $\mathrm{Rb}^{+}$over $\mathrm{Li}^{+}, \mathrm{Na}^{+}$, and $\mathrm{Cs}^{+}$. The copper complex has a larger affinity for the alkali metal cations than the free base or the nickel complex.

The electronic absorption and magnetic circular dichroism spectra of a bisphthalocyanine connected "inplane" by an 18-crown-6 ring (13, Chart 4) are not affected by complexation of alkaline or alkaline earth metal cations. ${ }^{55}$

\section{B. Porphyrins}

The first iron(III) porphyrin with four 15-crown-5 rings at the meso positions ([14e, $\mathrm{M}=\mathrm{Fe}$ (III), Chart 5] was synthesized by Kobayashi and Osa ${ }^{56}$ starting from 4-formylbenzo-15-crown-5 and pyrrole in $6 \%$ yield. Small but significant changes in the absorption spectra were observed upon complexation of $\mathrm{Na}^{+}$or $\mathrm{K}^{+}$, whereas $\mathrm{Li}^{+}$and $\mathrm{Cs}^{+}$have no effect. With $\mathrm{I}^{-}$as the counterionhigh spin complexes were obtained, but $\mathrm{CN}^{-}$as axial ligand gives a low-spin system. The redox potentials are hardly affected upon co-complexation of hard cations. Bogat-skii and Zhilina ${ }^{57}$ have reported the synthesis of meso-tetrakis(benzo-18-crown-6)porphyrin (14a) starting from 4-formylbenzo-18-crown-6 and 4-formylcatechol. Unfortunately no spectroscopic stud-

\section{Chart 5}

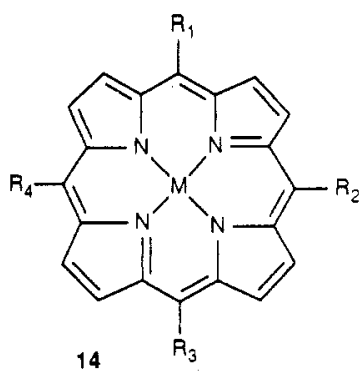

a $R_{1}=R_{2}=R_{3}=R_{4}=4$-benzo-18-crown-6

b $R_{1}=R_{2}=R_{3}=$ phenyl, $R_{4}=4 \cdot$ benzo-15.crown.5

c $R_{1}=R_{2}=$ phenyl, $R_{3}=R_{4}=4$-benzo-15-crown-5

d $R_{1}=$ phenyl, $R_{2}=R_{3}=R_{4}=4$-benzo-15-crown -5

e $R_{1}=R_{2}=R_{3}=R_{4}=4$-benzo-15-crown-5

$M=2 H, F e(I I I), \mathrm{Zn}(I I), \mathrm{Cu}\{I I), \mathrm{VO}(\mathrm{IV}), \mathrm{Mg}(I I), \mathrm{Mn}(I I I)$

ies of the co-complexation with hard cations were reported.

Krishnan et al.$^{58-60}$ have synthesized porphyrins with one to four benzo-15-crown-5 moieties at the meso positions (14b-e, Chart 5), by reacting a mixture of 4-formylbenzo-15-crown-5, benzaldehyde, and pyrrole. Upon co-complexation with $\mathrm{K}^{+}, \mathrm{NH}_{4}^{+}$, or $\mathrm{Ba}^{2+}$ dimerization occurs, with a stability increasing going from one to four crown ether moieties. The absorption spectra showed a blue-shift of the Soret band and a red-shift of the $Q$ band, accompanied by a broadening and a decrease in intensity. Dimerization leads to quenching of the fluorescence. From EPR measurements a copper-copper distance of $4.2 \AA$ was deduced in the $\mathrm{K}^{+}$-induced copperporphyrin dimer. The average distance decreases going from one to four benzo-15crown- 5 substituents. The one-electron oxidations of the porphyrin rings of the dimer take place at less anodic potentials than of the corresponding monomers. EPR data of the oxidized dimer (free base and zinc complexes) showed that the unpaired electron is localized in the $\pi$-system, unlike that observed for the "special pair" bacteriochlorophyll molecules of the bacterial photosynthetic system. ${ }^{60}$ These results were confirmed by van Willigen et al. ${ }^{61,62}$ by EPR, ENDOR, and absorption measurements for the dimerization of the tetrasubstituted porphyrin upon complexation of $\mathrm{K}^{+}$.

\section{Related Structures}

Related to the above-described porphyrins and phthalocyanines with crown ether moieties are the tetraaza[14] annulene derivatives 15 and 16 (Chart 6). Kruse and Breitmaier ${ }^{63}$ reported the nickel(II) and

\section{Chart 6}

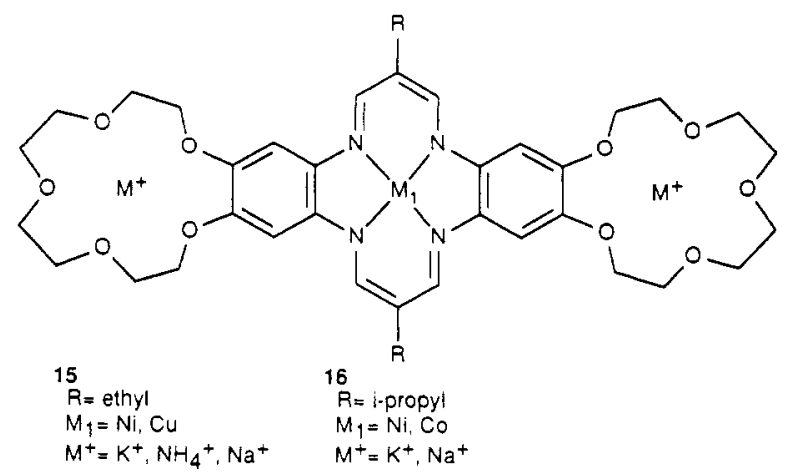




\section{Chart 7}

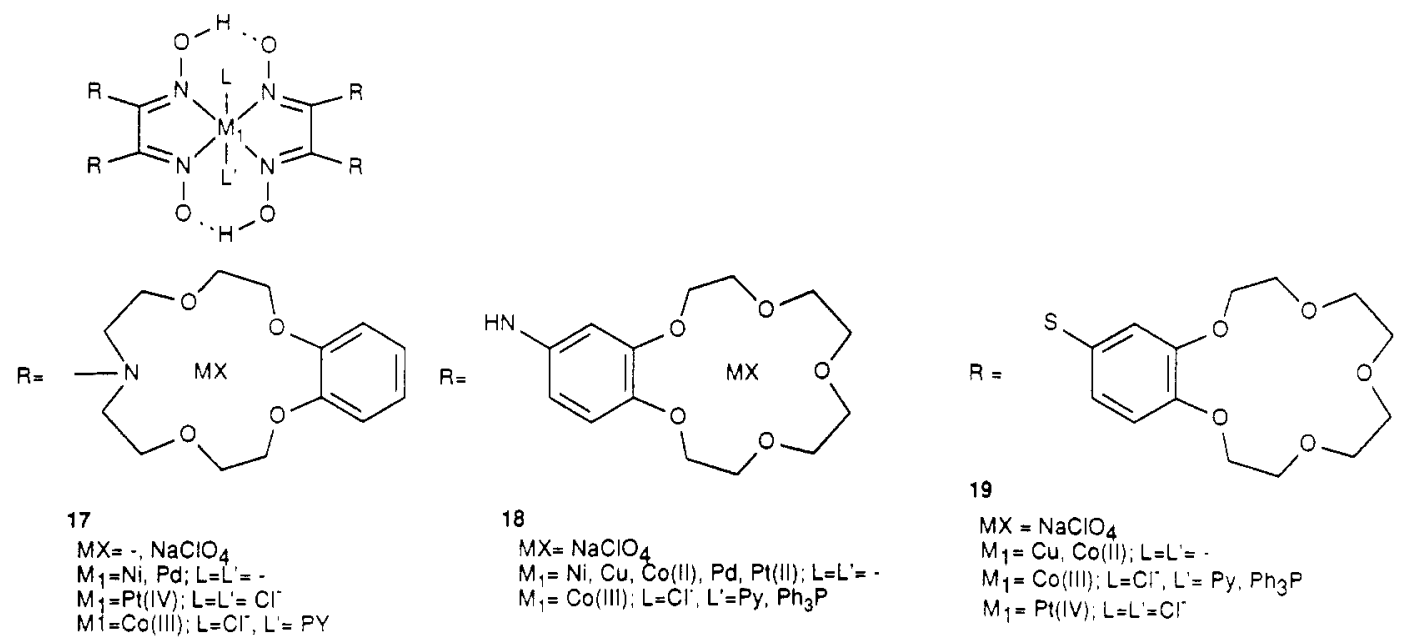

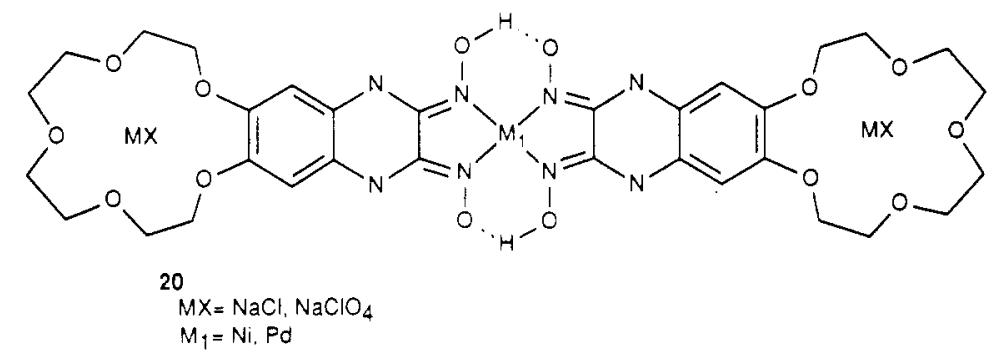

\section{Chart 8}

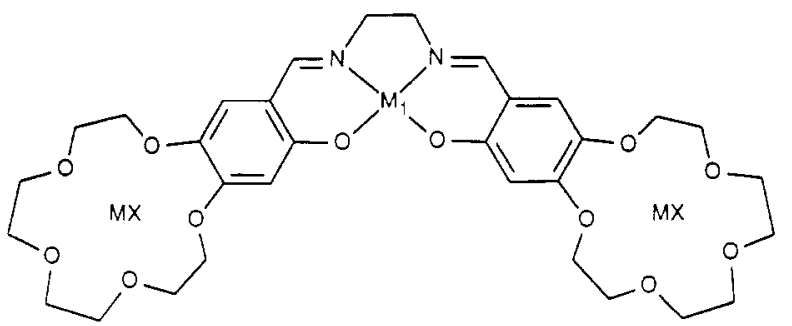

21 $\mathrm{M}_{1}=2 \mathrm{H}, \mathrm{CO}\left(1 \mathrm{i}, \mathrm{Ni}, \mathrm{Cu}, \mathrm{UO}_{2}\right.$ $M X=-, \mathrm{NaNO}_{3}$

\section{Chart 9}

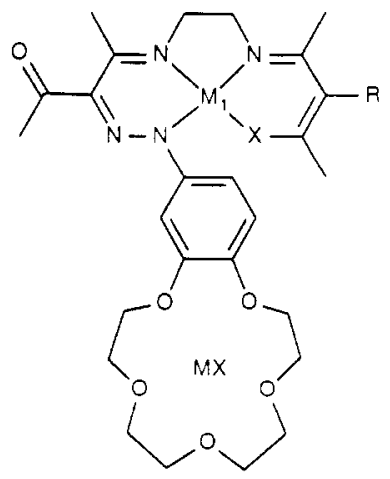

$\stackrel{22}{R=H}, X=O ; M_{1}=N i, C u$
cobalt(II) complexes 16 together with the co-complexation of KI and NaI. Sakata and Annoura ${ }^{64}$ reported the ethyl derivative 15 and showed by EPR spectroscopy that cofacial dimerization occurs upon co-complexation of $\mathrm{K}^{+}$or $\mathrm{NH}_{4}^{+}$, leading to a triplet state with axial symmetry. The co-complexation of $\mathrm{Na}^{+}$in the crown ether rings has no effect on the UV-vis spectra, but the co-complexation of $\mathrm{K}^{+}$or $\mathrm{NH}_{4}^{+}$has a profound effect. The hard cation induced dimers exhibit a reduced intensity of the absorption band in the $450-510-\mathrm{nm}$ region, broadening of the absorptions, and a blue-shift of the intense band in the 375-430-nm region.

$$
R=H, X=O ; M_{1}=N i, C u
$$
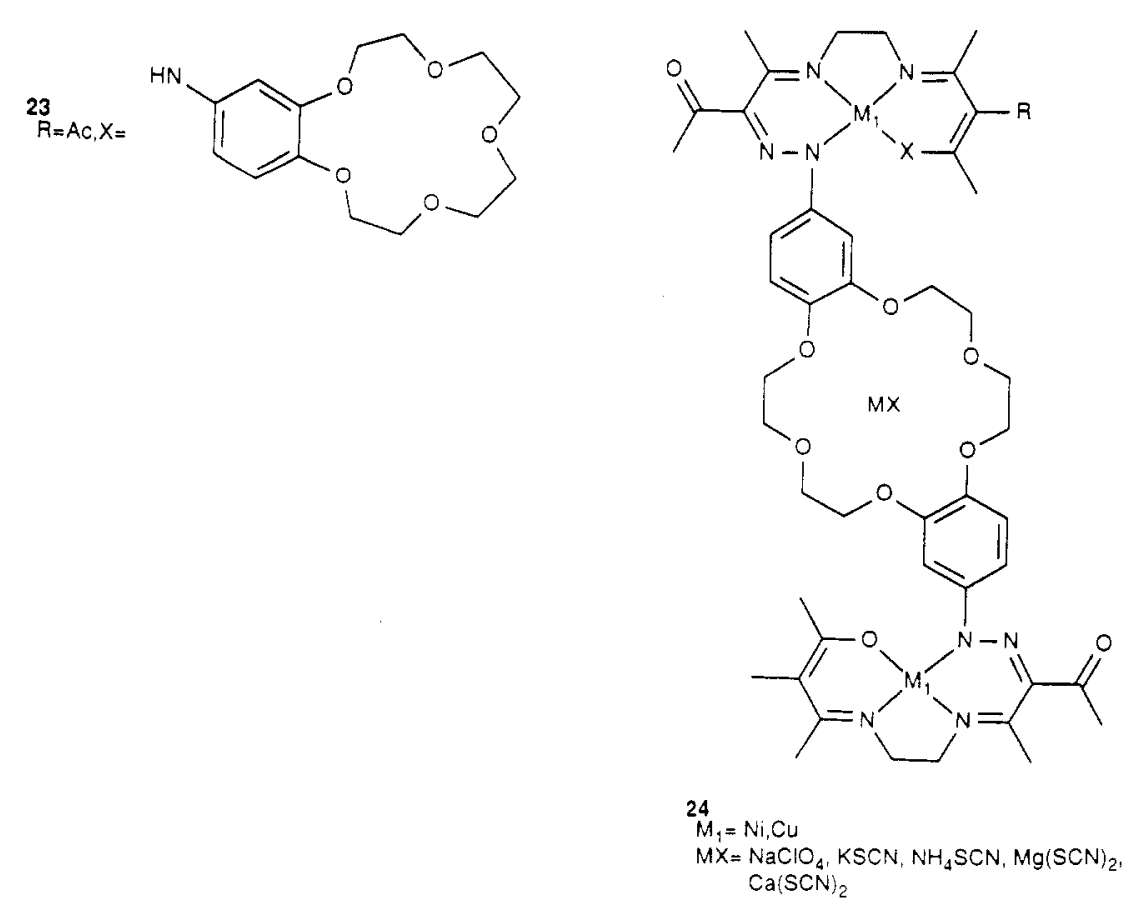


\section{Chart 10}
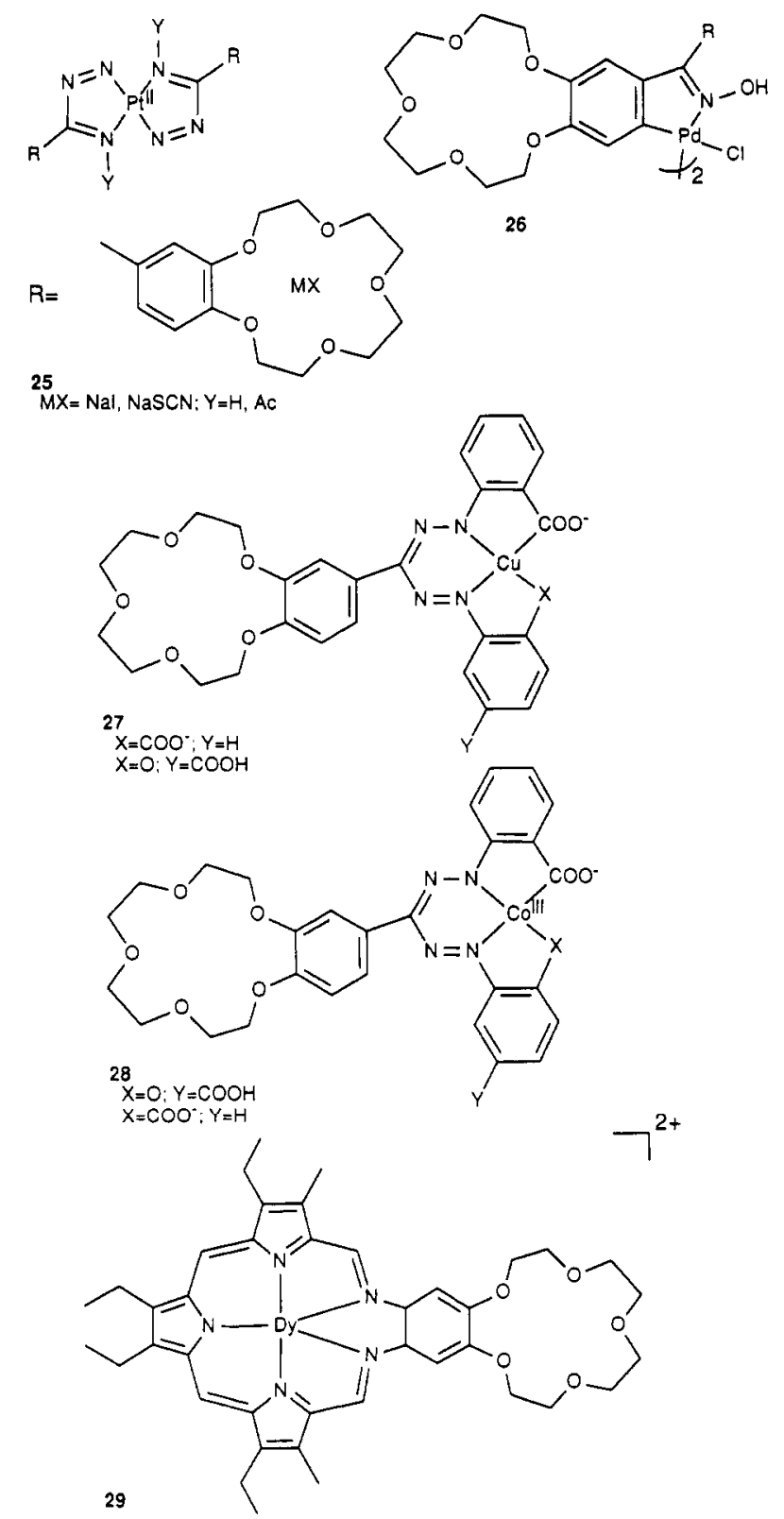

A number of bisglyoxime complexes with crown ether rings as substituents (17-20, Chart 7) have been reported by Bekâroğlu et al. ${ }^{65-68}$ The synthesis of the complexes 17-20 was achieved by reacting the appropriate glyoxime with substituted crown ether in $\mathrm{EtOH}$ in the presence of $\mathrm{NaHCO}_{3}$. The ${ }^{1} \mathrm{H}$ NMR, ${ }^{13} \mathrm{C} \mathrm{NMR}$, and IR spectra are not significantly affected by cocomplexation of $\mathrm{Na}^{+}$to the crown ethers. Extraction experiments of alkaline picrate salts from aqueous solutions into a $\mathrm{CH}_{2} \mathrm{Cl}_{2}$ layer containing the bisglyoxime complex showed a high extraction efficiency of $\mathrm{K}^{+}$, which may be due to sandwiching of the $\mathrm{K}^{+}$by two crown ether rings.

The synthesis of a salen type of ligand with two benzo15-crown-5 rings (21, Chart 8 ) has been achieved in five steps starting from benzo-15-crown-5. ${ }^{69}$ The order of the overall formation constants $\beta$ of the complexes is $\mathrm{CuL}(\log \beta=23.0), \mathrm{UO}_{2} \mathrm{~L}(\log \beta=20.6), \mathrm{NiL}(\log \beta=$ 15.1 ), and $\operatorname{CoL}(\log \beta 13.3$ ), as was determined by CalvinBjerrum $\mathrm{pH}$-titration techniques. The ${ }^{1} \mathrm{H} \mathrm{NMR},{ }^{13} \mathrm{C}$ NMR, and IR spectra are hardly affected by cocomplexation of $\mathrm{Na}^{+}$in the crown ethers. ${ }^{69}$
The azo-coupled di(tri)topic ligands 22-24 (Chart 9) were obtained by reacting the nickel or copper complex of bis(acetylacetoneimine) with the diazonium compound derived from aminobenzo-crown ethers. ${ }^{70}$ Electrical conductivity measurements in $\mathrm{CH}_{2} \mathrm{Cl}_{2}$ showed cation selectivity of $\mathrm{K}^{+}>\mathrm{Na}^{+}>\mathrm{NH}_{4}{ }^{+}$and $\mathrm{Ca}^{2+}>\mathrm{Mg}^{2+}$. The extraction efficiencies of the perchlorate salt from an aqueous layer into a $\mathrm{CH}_{2} \mathrm{Cl}_{2}$ layer are comparable to those of the "free" crown ethers, which means that the complexed transition metals hardly change the binding affinities of the crown ethers. The UV-vis and ${ }^{1} \mathrm{H}$ NMR spectra were not affected by co-complexation of hard cations in the crown ether rings.

Platinum complexes with benzocrown ether rings (25, Chart 10) have been synthesized by reacting $\mathrm{PtCl}_{2} \mathrm{~L}_{2}$ ( $\mathrm{L}=$ 4-cyanobenzo-15-crown-5) with hydrazine. ${ }^{71,72}$ The co-complexation of $\mathrm{Na}^{+}$was deduced from IR spectroscopy and elemental analysis. Cyclopalladation of 4 - $\left(\mathrm{CH}=\mathrm{NOH}\right.$ or $\mathrm{C}\left(\mathrm{CH}_{3}\right)=\mathrm{NOH}$ ) benzo-15-crown-5 leads to the chloro-bridged dipalladium complexes 26 . Mononuclear palladium complexes can be derived by reaction of 26 with $\mathrm{PPh}_{3}$ or $\mathrm{PMe}_{2} \mathrm{Ph}$. Potentially ditopic copper(II) and cobalt(III) complexes (27 and 28) have been reported, but no studies of co-complexation of hard cations are available. ${ }^{73}$ Sessler et al. ${ }^{74}$ reported the synthesis of the dysprosium complex 29 starting from the appropriate dialdehyde and 4,5-crowned 1,2-benzenediamine. ${ }^{23} \mathrm{Na} \mathrm{NMR}$ spectroscopy revealed a change of the chemical shift of $1.89 \mathrm{ppm}$ upon addition of 1 equiv of the dysprosium complex. The dimethyl ether analogue of the dysprosium complex induces a ${ }^{23} \mathrm{Na}$ chemical shift of $1.08 \mathrm{ppm}$, an indication that, despite the $2+$ charge, the crowned dysprosium complex is capable of complexing $\mathrm{Na}^{+}$.

\section{Activation of Carbon Monoxide}

Bifunctional activation of carbon monoxide may be achieved by dinuclear complexes that can coordinate to both the carbon and the oxygen atom. Transition metals have affinity for the carbon atom in carbon monoxide, whereas the oxygen atom is more likely to bind to alkali or alkaline earth metal cations.

Powell et al..$^{75-81}$ have demonstrated that the cocomplexation of $\mathrm{Li}^{+}$in metallocrown ethers, in which the $\mathrm{Li}^{+}$is also coordinated to one of the CO ligands (30-37, Chart 11), can activate this CO ligand toward nucleophilic attack. There are no reports on the reaction of $\mathrm{RLi}$ with cis- $\mathrm{M}(\mathrm{CO})_{4}\left(\mathrm{PR}_{3}\right)_{2}(\mathrm{M}=\mathrm{Cr}, \mathrm{Mo}$, $\mathrm{W})$, but the metallocrown ethers $30-37$ react with $\mathrm{RLi}$ leading to hetero-dinuclear complexes with an acyl or a benzoyl ligand which is both coordinated to the transition metal and to $\mathrm{Li}^{+}$. A systematic study showed that the reactivity is strongly dependent on the substituents of the phosphorus atoms. Stronger $\mathrm{Li}^{+}$ binding to the metallocrown ether leads to a larger reactivity. The metallocrown ether should coordinate to $\mathrm{Li}^{+}$in such a way that the $\mathrm{Li}^{+}$can also coordinate to the oxygen atom of $\mathrm{CO}$. It was further observed that the donor sites in the metallocrown ether should be as basic (hard) as possible. The molybdenum complexes 38 also react with $\mathrm{RLi}\left(\mathrm{R}=n-\mathrm{Bu}, t-\mathrm{Bu}, \mathrm{Et}_{2} \mathrm{~N}, i-\mathrm{Pr}_{2} \mathrm{~N}\right)$ to give complexes with a $\mathrm{R}-\mathrm{C}=\mathrm{O}$ ligand of which the carbonyl carbon is coordinated to the molybdenum and the carbonyl oxygen to the $\mathrm{Li}^{+} .81 \mathrm{~b} \mathrm{The}^{+} \mathrm{i}^{+}$is bound to the crown ether. The coordination of $\mathrm{Li}^{+}$and the molybdenum has been proven by a number of X-ray 
Chart 11<smiles>[R6]P1OCCCNC(=O)CC(C)OP1[14C]([2H])Cl</smiles>

30

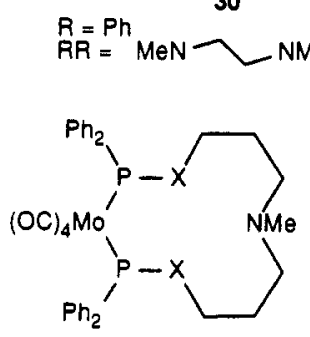

$33 \mathrm{X}=\mathrm{O}, \mathrm{NH}$

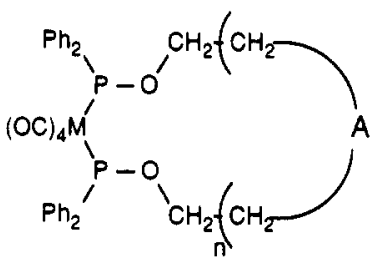

$35 n=1-4$

$\mathrm{A}=\mathrm{O}, \mathrm{NMe}$

$M=C r, M o, W$

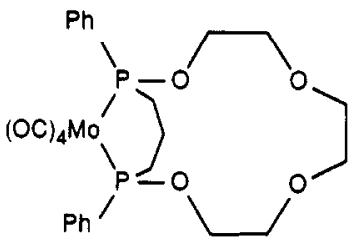

38<smiles>CC1C=CC=C[14C]([O-])=[14C]([O-])P(c2ccccc2)OCCOCCNC(=O)C1</smiles>

31

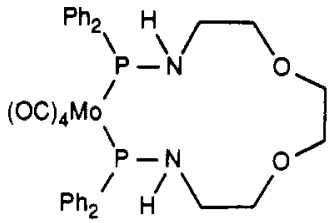

34<smiles>[X][Y]1([O-])CCO[PH]([X])([Y])OC[Y]CO1</smiles>

32

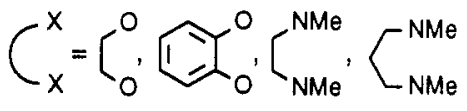

\section{$\mathrm{A}=\mathrm{CH}_{2} \mathrm{OCH}_{2} \mathrm{CH}_{2}$}

$\mathrm{A}=\mathrm{CH}_{2} \mathrm{CH}_{2} \mathrm{OCH}_{2} \mathrm{CH}_{2}$

$\mathrm{A}=\mathrm{CH}_{2} \mathrm{OCH}_{2} \mathrm{CH}_{2} \mathrm{OCH}_{2}$

$\mathrm{A}=\mathrm{CH}_{2} \mathrm{OCH}_{2} \mathrm{CH}_{2} \mathrm{OCH}_{2} \mathrm{CH}_{2}$

$\mathrm{A}=\mathrm{CH}_{2} \mathrm{~N}(\mathrm{Me})\left(\mathrm{CH}_{2}\right)_{3} \mathrm{~N}(\mathrm{Me}) \mathrm{CH}_{2}$<smiles>COCCN1CCOP(c2ccccc2)P(c2ccccc2)OP(c2ccccc2)O1</smiles>

36<smiles></smiles>

$37 \mathrm{Y}=\mathrm{OEt}, \mathrm{NEt}_{2}$<smiles>[O-][Pb]([P])(c1ccccc1)P(CN1CCOCCOCCOCCOCC1)c1ccccc1</smiles><smiles></smiles>

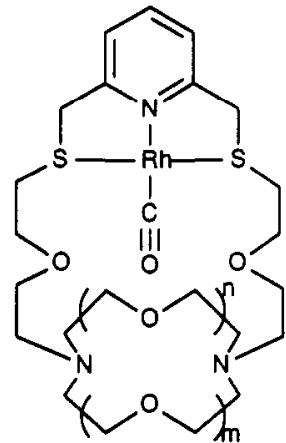

$40 \quad n=m=0$

$n=0, m=1$

$n=m=1$

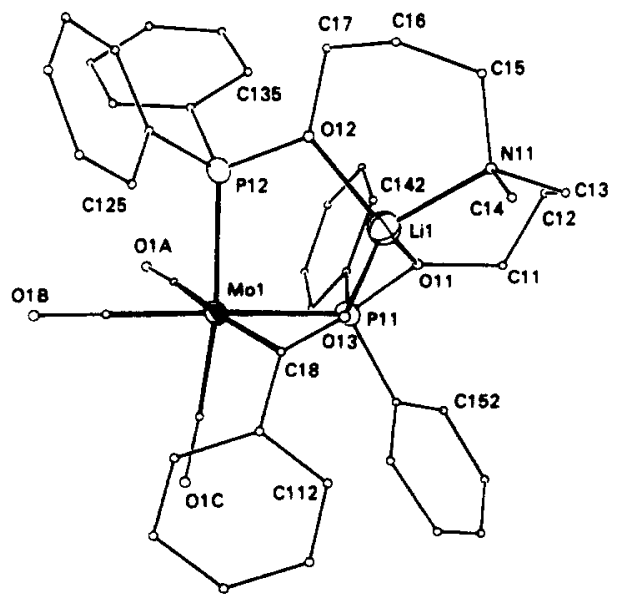

Figure 5. X-ray structure of $33(\mathrm{X}=0)$ reacted with $\mathrm{PhLi}$. (Reprinted from ref 81c. Copyright 1990 Munksgaard.) methods. ${ }^{81 b, c}$ Two representative examples are shown in Figures 5 and 6.

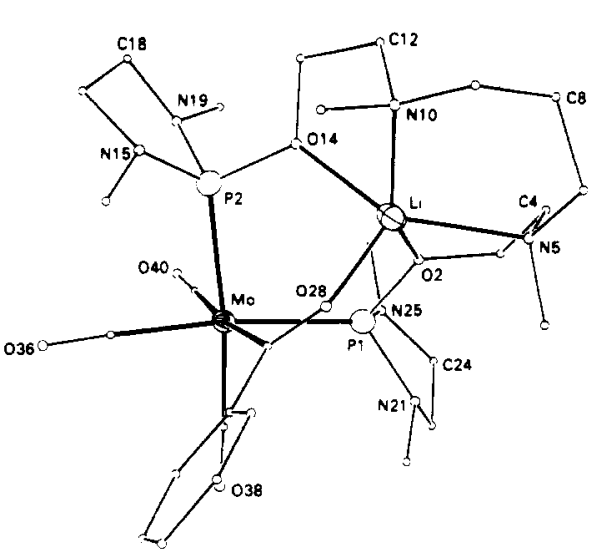

Figure 6. X-ray structure of $32\left[\mathrm{X}-\mathrm{X}=\mathrm{MeNCH}_{2} \mathrm{CH}_{2} \mathrm{NMe}\right.$, $\left.\mathrm{A}=\mathrm{CH}_{2} \mathrm{~N}(\mathrm{Me})\left(\mathrm{CH}_{2}\right)_{3} \mathrm{~N}(\mathrm{Me}) \mathrm{CH}_{2}\right]$ reacted with $\mathrm{PhLi}$. (Reprinted from ref 81c. Copyright 1990 Munksgaard.)

Cobalt and rhodium complexes of the monoazacrown ether $39 \mathrm{a}$ with co-complexed $\mathrm{Na}^{+}$or $\mathrm{Li}^{+}$are able to 
accelerate the hydroformylation of alkenes compared with the cobalt and rhodium complexes of $39 a^{82-84}$ For the analogous $\mathrm{Fe}$ (II) complexes $39 \mathrm{~b}, \mathrm{c}$ it has been shown that the association constant of $39 \mathbf{b} \cdot \mathrm{Na}^{+}$is larger than that of $39 \mathrm{c} \cdot \mathrm{Na}^{+}$due to coordination of the carbonyl oxygen atom of the acyl ligand in addition to the donor atoms of the crown ether. Besides a larger thermodynamic stability of $39 \mathrm{~b} \cdot \mathrm{Na}^{+}$also the kinetic stability is larger.

Rhodium(I) complexes with an intra-annular $\mathrm{CO}$ ligand containing also a diazacrown ether ring (40) have been reported by Carroy and Lehn. ${ }^{85}$ The co-complexation of hard cations to the diazacrown ring did not lead to a significant change of the ${ }^{13} \mathrm{CO}$ signal in the NMR spectrum and also the vibrational frequency $\nu$ (CO) was unchanged. The $\mathrm{CO}$ ligand is not activated by co-complexation of hard cations which is possibly due to co-complexation of the hard cations "on top" instead of inside the ligand.

\section{Blpyridlne- and Phenanthroline-Containing Ligands}

Rebek et al. ${ }^{86-88}$ have synthesized molecules 41 (Chart 12) capable of allosteric behavior due to both a $2,2^{\prime}$ -

\section{Chart 12}

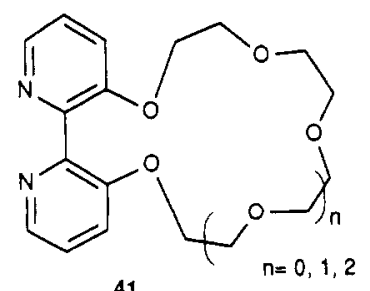

bipyridyl and a crown ether cavity. The two sites, although separated and electronically "insulated", do not behave independently. Chelation of a transition metal at the bipyridyl site forces restrictions on the conformational freedom of the macrocycle which is reflected in its selectivity for the complexation of alkaline metal cations. The importance of this type of compound for enzymatic catalysis and details on the complexation are given in a recent review article. ${ }^{89}$ Allosteric biscrown ether ligands containing a 2,2'bipyridyl fragment have been developed by Beer et al. ${ }^{90,91}$ Chelation of a transition metal at the bipyridyl site forces the bipyridyl function toward coplanarity, restricting the conformational freedom of the two benzocrown ether moieties but favoring the formation of intramolecular sandwich complexes with spherical alkali metal cations (42, Chart 13). The results of this study have been summarized in a review on redox responsive macrocyclic receptor molecules. ${ }^{92}$ Recently Beer et al. ${ }^{93,94}$ also prepared alkynyl- (43) and vinyllinked $(44,45)$ benzo- and azacrown ether bipyridyl complexes. Heteropolymetallic ruthenium(II)-sodium complexes, in which each crown ether binds one sodium cation, were isolated from complexation reactions of the Ru(II) complexes of 42-44 with excess amounts of sodium hexafluorophosphate. Fluorescence spectroscopy revealed the recognition of $\mathrm{Li}^{+}, \mathrm{Na}^{+}$, or $\mathrm{Mg}^{2+}$ by the vinyl-linked crown ether bipyridyl Ru(II) complexes. The metal-to-ligand charge transfer emission maxima for the complexes are shifted to significantly lower wavelengths and increase in intensity upon the addition of the cation. The Ru(II) complexes of 42-44 could be easily electropolymerized onto platinum and optically transparent conducting glass electrodes to form films.

\section{Chart 13}
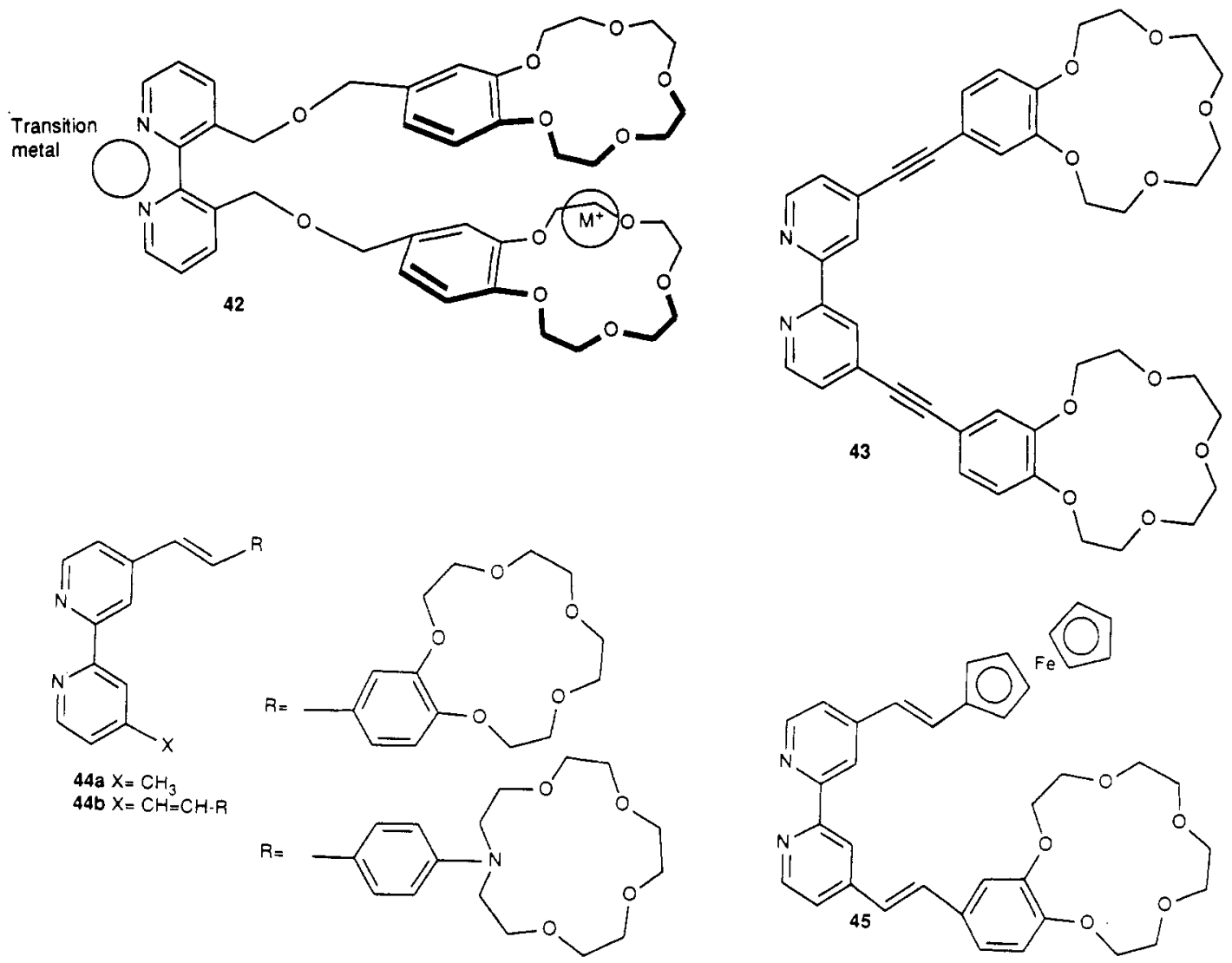
Chart 14
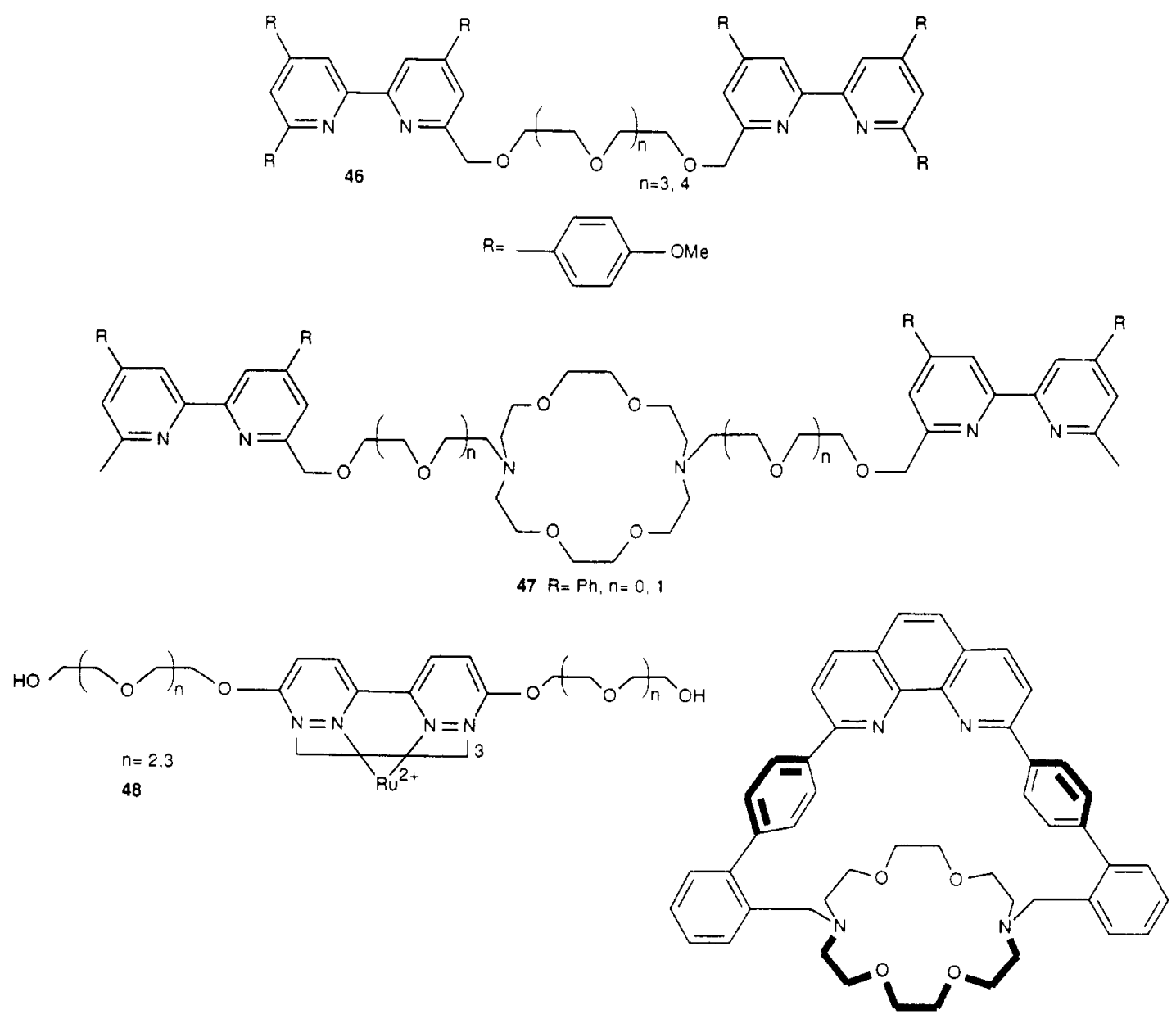

49

Although electrochemical recognition by such modified electrodes has not been observed, such systems show promise as novel spectrochemical sensors. By using step-by-step lithiation of 4,4'-dimethyl-2,2'-bipyridine Beer et al..$^{95}$ prepared in a one-pot synthesis the polytopic 2,2 '-bipyridyl ligand $\mathbf{4 5}$ containing both a benzocrown ether and a ferrocene moiety. Preliminary coordination studies reveal that $\mathbf{4 5}$ forms a heteropolymetallic ruthenium(II)-ferrocene-sodium cation complex, of which the photo- and electrochemical properties have not yet been published.

Another type of allosteric ionophores are compounds 46 (Chart 14) consisting of two substituted bipyridine units connected at the $\alpha$-position with a (poly)ethyleneoxy chain. ${ }^{96-98}$ These compounds can be prepared in $50-60 \%$ yield by treatment of mono(bromomethyl)bipyridine derivatives with ethylene glycol oligomers in the presence of potassium hydroxide in dry dioxane as a solvent. $\mathrm{A} \mathrm{K}^{+} / \mathrm{Na}^{+}$selectivity of about 10 was observed in transport experiments across $\mathrm{CH}_{2}$ $\mathrm{Cl}_{2}$ as a liquid membrane using ionophore 46 in the presence of $\mathrm{Cu}^{+}, 500-\mathrm{MHz}{ }^{1} \mathrm{H}$ NMR spectroscopy proved the formation of a cyclic pseudocrown ether structure upon the addition of $\mathrm{Cu}^{+}$to ionophore 46 , which may explain the transport selectivity found. Similar results were obtained with 47 in which the $2,2^{\prime}$-bipyridine moieties are connected with a diazacrown ether. ${ }^{99}$ Ionophores 47 selectively complex $\mathrm{Cu}^{+}$ and $\mathrm{Zn}^{2+}$ under simultaneous formation of a pseudocryptand which gives rise to selective complexa- tion of alkaline metal cations.

The water-soluble ruthenium(2+) complexes 48 (Chart 14) have recently been described by Dürr et al. ${ }^{100}$ Addition of alkali and alkaline earth cations to a solution of the ruthenium complex in acetonitrile leads to an increase of both the fluorescence quantum yield and the lifetime of the excited state. Analysis of titration data showed that 1:1 complexes are formed, which was not expected. The ruthenium complex 48 $(n=1)$ has a selectivity of $\mathrm{Ca}^{2+}$ and $\mathrm{Ba}^{2+}$ over $\mathrm{Li}^{+}, \mathrm{Na}^{+}$, and $\mathrm{Mg}^{2+}$. The ruthenium complex $48(n=2)$ has a large selectivity of $\mathrm{Ca}^{2+}$ over $\mathrm{Ba}^{2+}, \mathrm{Li}^{+}, \mathrm{Na}^{+}$, and $\mathrm{Mg}^{2+}$. Wytko and Weiss reported the synthesis of the macrobicyclic hard and soft ligand 49 containing an 0 -phenanthroline subunit and an azacrown ether. ${ }^{101}$ The biphenyl spacer ensures the rigidity of the molecular framework and, consequently, the high degree of preorganization of the ligand. The formation of copper(I)- and rhodium(I)-alkali complexes is still under investigation. Recently the same group published the synthesis of a related molecule viz. a highly rigid phenanthroline-capped porphyrin which contains two different soft donor sites. ${ }^{102}$

\section{Ferrocenophanes and Ruthenocenophanes}

Macrocyclic compounds containing a ferrocene moiety, so-called ferrocenophanes, have received considerable attention. Their ability to complex metal cations offers the possibility for the interaction between two 


\section{Scheme 2}

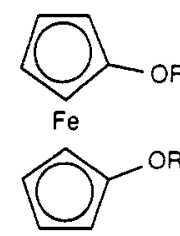

$50 \mathrm{R}=\mathrm{H}$ $53 R=A C$

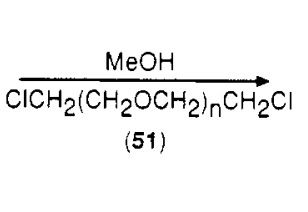

1) $\mathrm{KOH} / 18-\mathrm{C}-6$ 2) 51
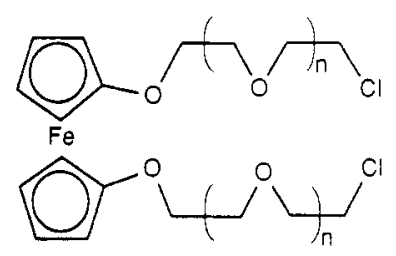

55
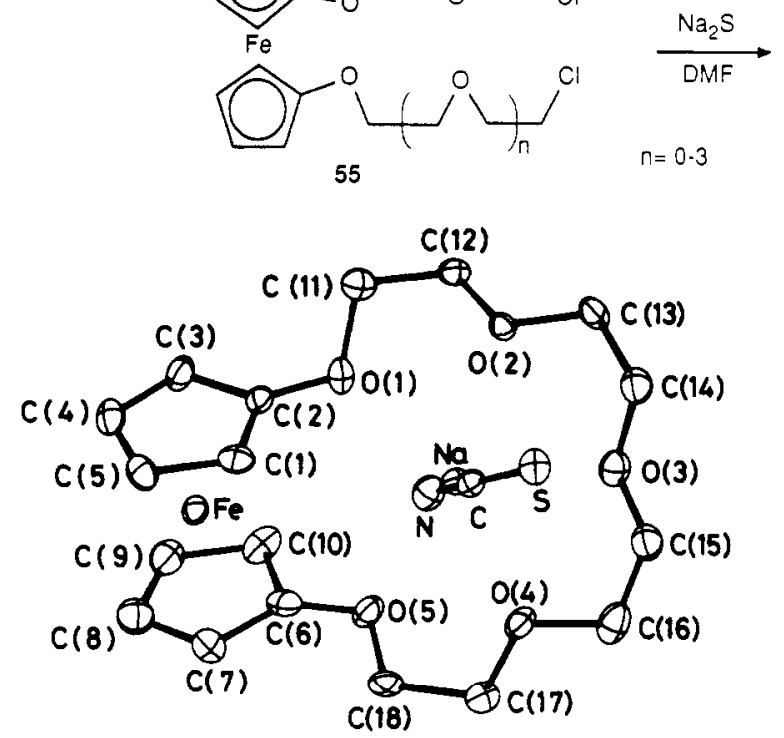

Figure 7. X-ray structure of $52(n=3) \cdot \mathrm{NaSCN}$. (Reprinted from ref 108. Copyright 1984 Nippon Kagakki.)

metal centers. In particular, such compounds yield redox-active host molecules that can be used for selective recognition of cations. As outlined in the Introduction, only systems having a cavity for the complexation of hard cations will be discussed. Several corresponding thiaferrocenophanes and related compounds have been described in the literature, which are very suitable for the complexation of heavy metal cations. ${ }^{103-105}$

Biernat and Wilczewskia ${ }^{106}$ reported the reaction of $1,1^{\prime}$-dihydroxyferrocene (50) with dichloro ethers 51 in the presence of sodium hydroxide to give the polyoxaferrocenophanes $\mathbf{5 2}$ in $17-36 \%$ yield (Scheme 2). The same reaction was performed by Akabori et al. ${ }^{107}$ using in situ prepared 50 from 1,1'-diacetoxyferrocene (53) and potassium hydroxide as a base to afford compounds 52 in increased yields of $25-60 \%$.

The yields are dependent on the size of the ring and decrease in the order $n=4>3>2>1>0$. It has been postulated that the potassium cation acts as a template in the cyclization. These polyoxaferrocenophanes extract to some extent alkali and alkaline earth metal cations from aqueous solutions. The extraction is less efficient from the corresponding benzocrown ethers, indicating that the incorporation of the soft iron atom of the ferrocene unit into the macrocyclic polyether ring has a considerable influence on the complexing ability with hard alkali and alkaline earth metal cations. On the other hand, a significant selectivity of $52(n=$ $3,4)$ was found toward the thallium(I) ion. ${ }^{1} \mathrm{H}$ NMR

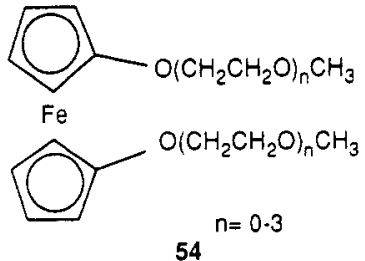

52

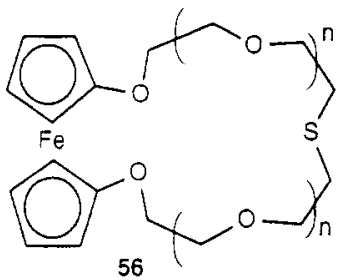

and Mössbauer spectroscopy of the complexes of $\mathbf{5 2}(n$ =4) with LiSCN and KSCN suggest a certain interaction between the iron atom of the ferrocene unit and the complexed cation. However, an X-ray structure determination of the complex of $\mathbf{5 2}(n=3)$ with NaSCN (Figure 7) revealed that the iron atom of the ferrocene does not take part directly in complex formation and that the sodium cation forms a contact ion pair with the nitrogen atom of the counteranion. ${ }^{108}$ In a similar reaction Akabori et al. ${ }^{109}$ also prepared the acyclic ferrocene-containing polyethers 54 in $53-85 \%$ yield. Compared with 52 they even exhibited less extraction of alkali metal cations although to some extent they extract alkaline earth cations. The extraction of monovalent cations by $54(n=3)$ increases in the order $\mathrm{Na}^{+}<\mathrm{Li}^{+}<\mathrm{K}^{+}<\mathrm{Cs}^{+}<\mathrm{Tl}^{+}<\mathrm{Ag}^{+}$.

When the reaction of $1,1^{\prime}$-diacetoxyferrocene (53) with dichloro ethers 51 was carried out in the presence of 18 -crown- 6 as phase-transfer catalyst the $1,1^{\prime}$-bis[ $\omega$-chloropoly(ethyleneoxy)]ferrocenes (55) were obtained in 26-54\% yield together with small amounts of the polyoxaferrocenophanes $52 .{ }^{110}$ Reaction of 55 with sodium sulfide in DMF at reflux temperature gave polyoxathiaferrocenophanes 56 in 21-66\% yield. Due to the presence of the soft sulfur atom, the extraction of alkali metal cations was lower than in the case of ferrocenophanes 52. However, compound $56(n=3)$ extracts efficiently thallium(I) cations. Lariat ferrocenocrown ethers corresponding to $\mathbf{5 2}$ have been synthesized and these hardly extract alkali metal cations. ${ }^{111}$

Another class of ferrocenophanes are those compounds in which the polyether chain via a $\mathrm{XCH}_{2}$ bond is connected with the ferrocene moiety. Czech et al. ${ }^{112}$ investigated the reaction of $1,1^{\prime}$-bis ( $\alpha$-hydroxyethyl)ferrocenes (57) with dithiols 59 in $\mathrm{CH}_{2} \mathrm{Cl}_{2}$ in the presence of a catalytic amount of trifluoroacetic acid under conditions of high dilution (Scheme 3 ). Reaction of $\mathbf{5 7}$ with 2,2'-dimercaptodiethyl ether $59(n=0)$ gave the mononuclear oxadithia[9] ferrocenophane $60(n=0)$ and dinuclear dioxatetrathia[9.9]ferrocenophanes 61 $(n=0)$, the latter being the major reaction product. When $\mathrm{R}=\mathrm{H}$ in both cases mixtures of separable diastereomers were obtained. However, when the reaction was performed with dithiols $59(n=1,2)$ having a longer ethyleneoxy chain mononuclear 60 was the 
Scheme 3

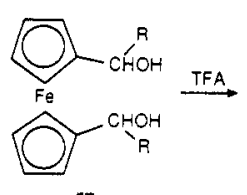

57

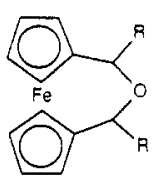

58

$R=H_{1}, M e$
$\eta=0,1,2$

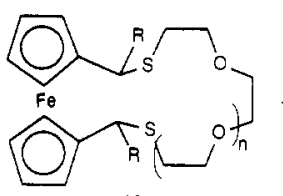

60

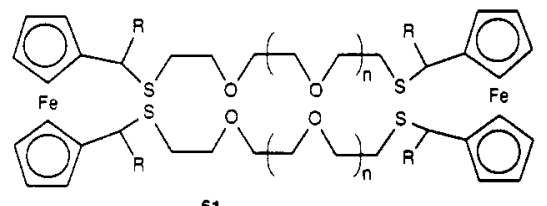

61

Scheme 4
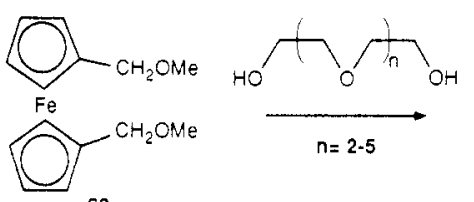

62

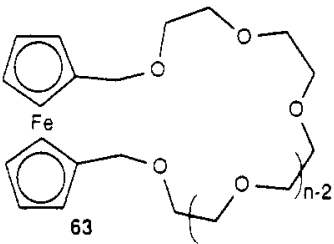

predominant reaction product (e.g. $\mathrm{R}=\mathrm{H}, n=1,2$, $89 \%$ ), while only very low yields were isolated of $61.113,114$ It was proven that the first step of the reaction of $\mathbf{5 7}$ with dithiols 59 is a very fast formation of the cyclic ethers 58. Starting from a mixture of diastereomeric 57 first a mixture of trans- and cis-58 was formed giving rise to rac- and meso-60, respectively. The structure of meso-60 $(n=2)$ has been proven with X-ray crystallography. ${ }^{115}$

Recently, Petter et al. ${ }^{116}$ have discovered that this result is not limited to thioethers. Starting from 1,1'bis(methoxymethyl)ferrocene (62) the corresponding polyoxaferrocenophanes $63(n=2-5)$ were obtained in $14-31 \%$ yield (Scheme 4 ).

Oxaferrocenophanes $63(n=2-4)$ were also prepared by Akabori et al. ${ }^{117}$ by reaction of $57(\mathrm{R}=\mathrm{H})$ with the appropriate oligoethylene glycol ditosylates or the corresponding dihalides using potassium tert-butoxide as a base; besides a low yield of $63(3-13 \%)$, very small amounts of the dinuclear product were also obtained. From extraction experiments it was found that oxaferrocenophanes 63 show little or no complexing ability toward alkali metal cations. This in contrast to thallium(I) and silver cations for which a high complexing ability was found. These results correspond with those obtained for the ferrocenophanes $\mathbf{5 2}$. It is noteworthy that compounds 63 are able to form a stable complex with silver without decomposition, whereas compounds 52 decomposed rapidly in the presence of silver ions. This indicates that the distance between the iron atom of the ferrocene nucleus and the complexed silver cation controls the rate of oxidation of the ferrocene moiety.

In compounds like 63 , the macrocycle is formed at the $1,1^{\prime}$-positions of the ferrocene ring. Izumi et al. ${ }^{118}$ have prepared ferrocenophanes 64 and 65 (Chart 15) which contain crown ether type units connected at the 1,2- or 1,3-positions of one of the cyclopentadienyl rings. Compounds 64 and 65 were obtained in $6-17 \%$ yield by reaction of 1,2- or 1,3-bis (hydroxymethyl)ferrocene, respectively, with oligoethylene glycol ditosylates using
Chart 15

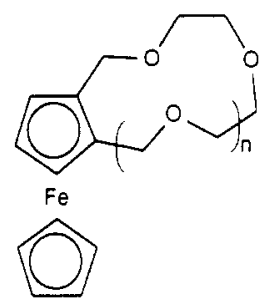

$64 n=2 \cdot 5$
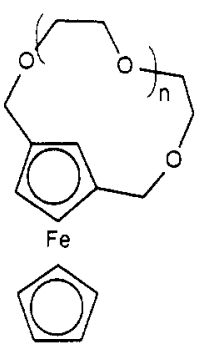

$65 n=2 \cdot 5$
Scheme 5
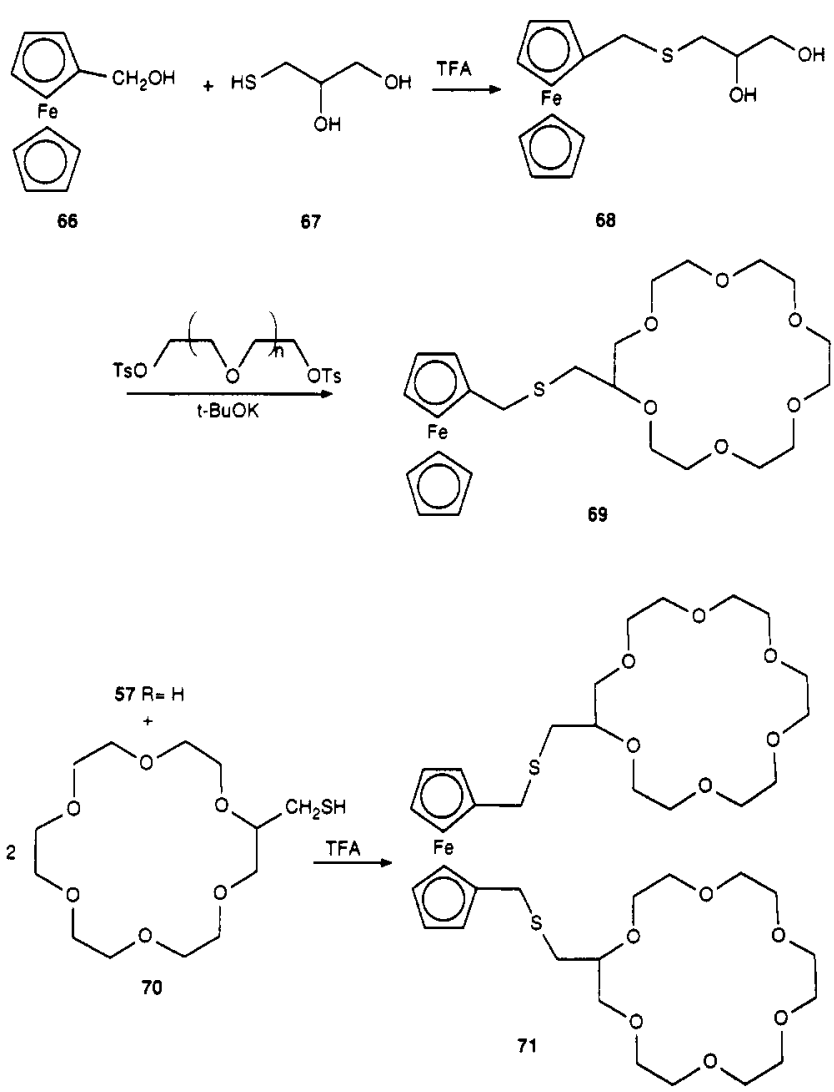

potassium tert-butoxide as a base. In extraction experiments 64 and 65 also exhibit a high selectivity toward thallium cation (vide supra). Although the extraction of alkali metal cations is modest, 1,2ferrocenophanes 64 show a higher complexing ability than 1,3-ferrocenophanes 65 , even though the latter have a somewhat larger ring size. This may be explained by assuming that the proton at the 2-position of the cyclopentadienyl ring of 65 is sterically hindering in the complexation process.

Bartsch et al. ${ }^{119}$ investigated ferrocene crown compounds 69 and 71 in which the ferrocene nucleus bears one and two 18-crown-6 units, respectively. (Hydroxymethyl)ferrocene 66 was reacted with 3-mercapto1,2-propanediol (67) in the presence of trifluoroacetic acid to give 68 in $82 \%$ yield which was cyclized with the ditosylate of pentaethylene glycol in the presence of potassium tert-butoxide to ferrocene crown 69 which was obtained in $20 \%$ yield (Scheme 5). The corresponding ferrocene biscrown 71 was prepared in $88 \%$ yield by reaction of bis(hydroxymethyl)ferrocene (57, $\mathrm{R}=\mathrm{H}$ ) with 2 equiv of (mercaptomethyl)-18-crown-6 (70). Extraction experiments with KSCN showed a potassium loading of $44 \%$ and $128 \%$ for 69 and 71 , 
Scheme 6<smiles>O=[C]c1ccccc1-c1cccc(C=O)c1</smiles>

$72 \mathrm{M}=\mathrm{Fe}$

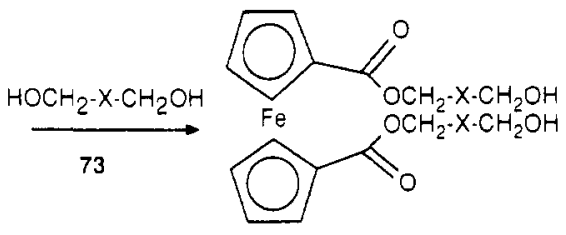

74

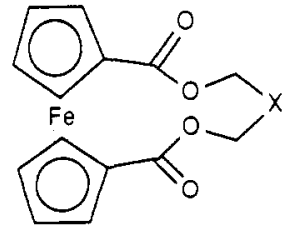

75

a $X=\left(\mathrm{CH}_{2} \mathrm{OCH}_{2}\right)_{n} ; \mathrm{n}=0.3$<smiles>Cc1cccc(C)n1</smiles>

c $X=$<smiles>Cc1ccc(C)s1</smiles>

$d x=$<smiles>Cc1cccc(C)c1</smiles>

eX $=\mathrm{CH}_{2} \cdot \mathrm{S} \cdot \mathrm{CH}_{2}$<smiles>[X]COC(=O)c1ccccc1C(=O)OCCOC(=O)c1ccccc1C(=O)c1ccccc1</smiles>

76

Scheme 7

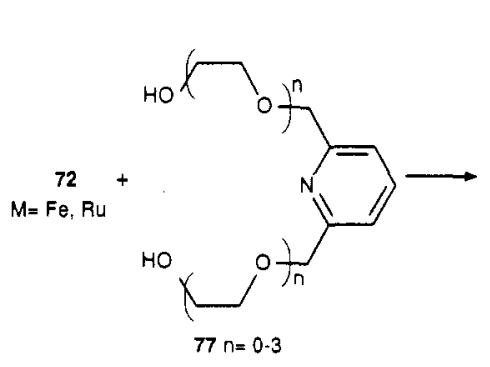

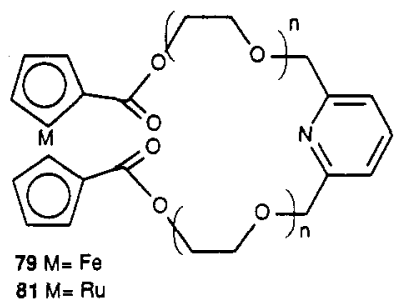

respectively, indicating that 71 adopts conformations in which the two crown ether units act independently rather than to form sandwich complexes. For the ferrocene biscrown 71 a selectivity was found in the order $\mathrm{K}^{+}>\mathrm{Rb}^{+} \gg \mathrm{Na}^{+}$and $\mathrm{Li}^{+}$and $\mathrm{Cs}^{+}$being undetectable.

A third type of ferrocenophanes comprises compounds in which the ferrocene unit is connected via a carbonyl moiety to the polyether chain. Oepen and Vogtle ${ }^{120}$ reported that in the presence of pyridine reaction of $1,1^{\prime}$-bis (chlorocarbonyl)ferrocene (72) with diols $73\left(\mathrm{X}=\left(\mathrm{CH}_{2} \mathrm{OCH}_{2}\right)_{n} ; n=1-3\right)$ in benzene led to the formation of oxaferrocenophanes $75 \mathbf{a}$ in $29-36 \%$ yield (Scheme 6). Izumi et al. ${ }^{121}$ reinvestigated this reaction in the absence of pyridine and found in all cases in addition to $75 \mathbf{a}$ the $1,1^{\prime}$-ferrocenediyl dialcohol derivatives $\mathbf{7 4 a}$ as the major reaction product. Similarly, however, in the presence of triethylamine, compounds $74 b-e(2-9 \%$ yield) and $75 b-e(19-67 \%$ yield) were prepared. The dinuclear ferrocenophanes $\mathbf{7 6 a - e}$ were obtained by reaction of $74 \mathbf{a}-\mathbf{e}$ with an additional equivalent of 72 in yields of 23-29\% (a,d) and $5 \%$ (b,c,e). Ferrocenophanes $75 \mathbf{a}$ and $\mathbf{7 6 a}$ showed low complexing ability with alkali, alkaline earth, and transition metal cations without any difference in the extractability, analogously as found for 52 (vide supra).

Dinuclear ferrocenophanes $76 \mathrm{c}$ and $76 \mathrm{e}$ containing an additional soft donor atom exhibited high complexing ability toward silver and mercury (under acidic conditions) cations without decomposition of the ferrocene unit. In contrast to many other ferrocenophanes, both 75 and 76 showed a poor complexing ability toward thallium(I) cation probably due to the incompatability of the guest and the hole size of the host. A series of pyridine-containing ferrocenophanes 79 and the corresponding ruthenophanes 81 , both with different sizes of the cavity, have been prepared in the same way as described above (Scheme 7) and their complexation behavior studied. 122 The pyridinometallocenophanes 79 and 81 showed a similar low extraction of alkali and alkaline earth metal cations and a high extractability toward heavy-metal cations, in particular for silver, indium ( $\left.\mathrm{In}^{3+}\right)$ and zirconium $\left(\mathrm{Zr}^{4+}\right)$ cations. In general, ferrocenophanes 79 extract alkali and alkaline earth cations better than ruthenocenophanes 81 .

Ferrocenocryptands 82 (Chart 16) have been studied by Hall et al. ${ }^{92,123}$ Extraction studies with alkali and alkaline earth metal cations indicated that $\mathbf{8 2}$ shows a specificity which follows the order $\mathrm{Ca}^{2+} \gg \mathrm{K}^{+}>\mathrm{Mg}^{2+}$ $\approx \mathrm{Na}^{+} \gg \mathrm{K}^{+}$. The interaction of $82(n=1)$ with a range

\section{Chart 16}

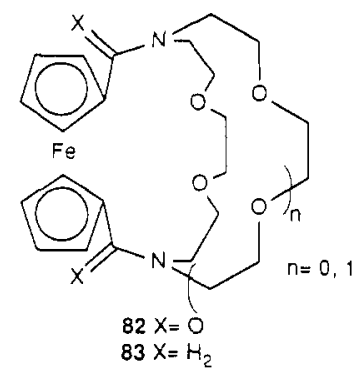




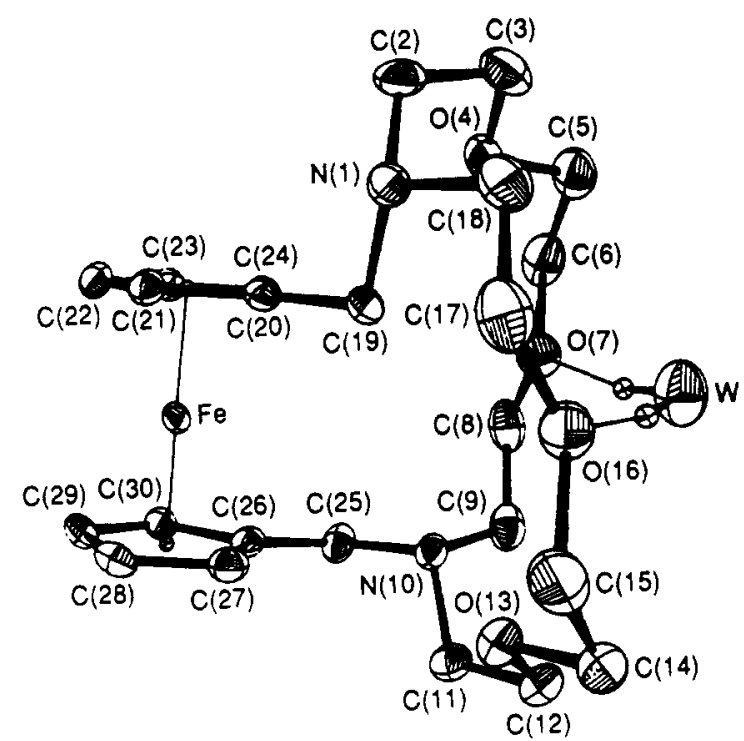

Figure 8. X-ray structure of $83(n=1) \cdot \mathrm{H}_{2} \mathrm{O}$. (Reprinted from ref 126 . Copyright 1991 Royal Society of Chemistry.)

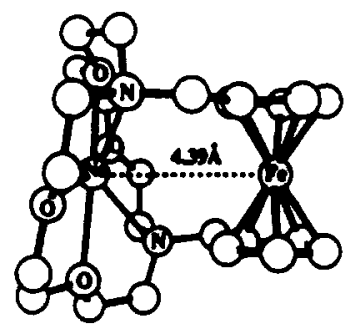

Figure 9. X-ray structure $83(n=1) \cdot \mathrm{NaClO}_{4}$. (Reprinted from ref 127. Copyright 1992 American Chemical Society.)

of divalent cations has been examined by ${ }^{13} \mathrm{C}$ NMR spectroscopy, and this revealed the formation of $1: 1$ and 2:1 (host/guest) complexes in a ratio dependent on the conditions. ${ }^{124}$ Several 1:1 complexes (with $\mathrm{Mg}^{2+}$, $\mathrm{Ca}^{2+}, \mathrm{Sr}^{2+}, \mathrm{Ba}^{2+}, \mathrm{Zn}^{2+}$ ) have been isolated and characterized confirming the conclusions reached by ${ }^{13} \mathrm{C}$ NMR spectroscopy. Hall et al. ${ }^{125}$ also reported the first solid-state crystal structure of an asymmetric ferrocene containing cryptand [82 $(n=0)]$. Recently Gokel et al. ${ }^{126,127}$ investigated the behavior of ferrocenyldimethyl[2.2] cryptand 83 by reduction of $82(n=1)$ with $\mathrm{LiAlH}_{4}$. The crystal structure of $83(n=1) \cdot \mathrm{H}_{2} \mathrm{O}$ (Figure 8) contrasts sharply with that of $82(n=1) \cdot\left(\mathrm{H}_{2} \mathrm{O}\right)_{2}$ in that in the former two hydrogen bonds hold a single water molecule to the external face of the diaza-18-crown-6 subunit, whereas two water molecules are present in the structure of $\mathbf{8 2}$. In the latter one, water is coordinated to a carbonyl group and the other appears to fill a molecular void outside the ring. Compound $\mathbf{8 3}$ exhibits an electrochemical behavior that is strongly dependent on alkali and alkaline earth metal cations present. This is due to a combination of nitrogen atom basicity and greater conformational mobility of 83 compared with $82(n=1)$. Cyclic voltammetry of $83 \cdot \mathrm{H}_{2} \mathrm{O}$ in the presence of e.g. sodium perchlorate revealed that the oxidation of the $\mathrm{Na}^{+}$complex takes place at more positive potentials than the oxidation of the free ligand. From this it can be concluded that the ferricinium (oxidized) form of the complex is destabilized by repulsive electrostatic interactions with the coordinated cation. The X-ray analysis of $83(n=$ 1). $\mathrm{NaClO}_{4}$ showed that the $\mathrm{Na}^{+}$is coordinated to the donor atoms of the crown ether at a distance of $4.39 \AA$
Scheme 8

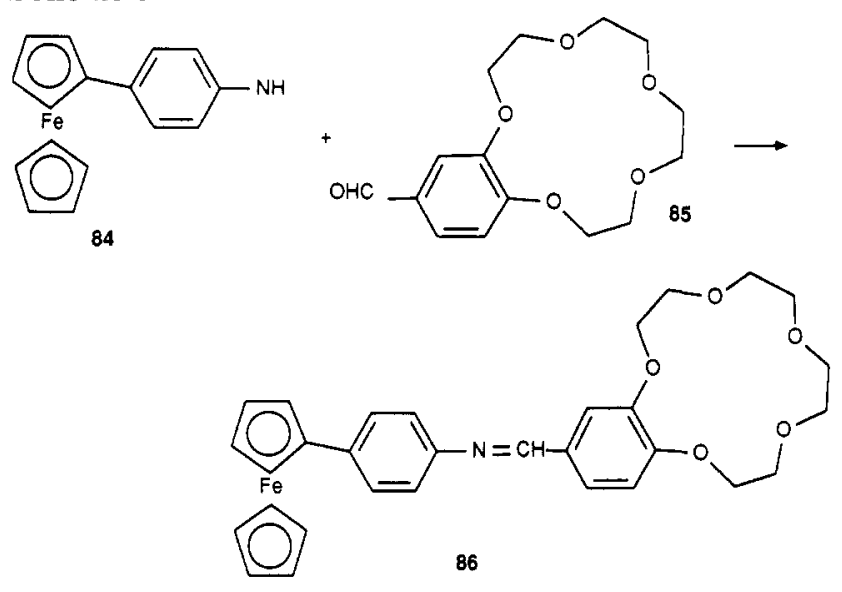

Chart 17
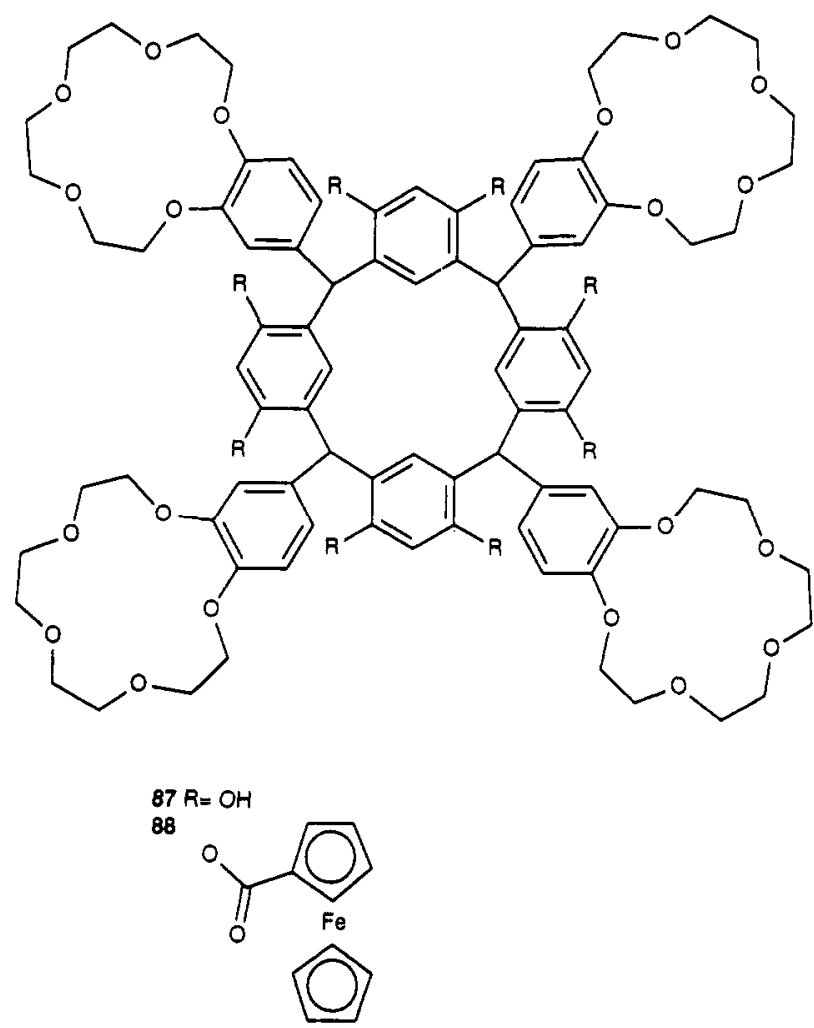

from the Fe atom (Figure 9). ${ }^{127}$

Beer et al. have extensively studied the electrochemical recognition of charged species by redox-active ferrocene or ruthenocene containing macrocycles either by "through space" electrostatic perturbation and/or via various conjugated bond linkages linking the heteroatoms of the ionophore to the redox center. A combination of different factors contribute to the experimentally observed magnitude and type (one or two waves) of the shift in the respective redox couples of these host systems produced by charged-guest binding. These include (i) the redox-active host-guest complementarity, (ii) the polarizing power of the guest, (iii) the proximity of the host binding site to the redox center, and (iv) the nature of the bond linkage from the host binding site to the redox center. The results of their investigations and those of a few other groups have recently been reviewed ${ }^{92}$ and consequently are not incorporated in this review. Recently Beer et al. ${ }^{128,129}$ also reported redox-responsive receptors 86 in 
which a ferrocene moiety is linked to a benzo-15-crown-5 cation binding unit via a conjugated Schiff base bond. Compound 86 was prepared in $55 \%$ yield by reaction of 4-ferrocenylaniline 84 and 4-formylbenzo-15-crown-5 (85) (Scheme 8). With the use of cyclic voltammetry the reversible redox couple of 86 shifts anodically upon the addition of $\mathrm{Na}^{+}, \mathrm{K}^{+}$, or $\mathrm{Mg}^{2+}$ cations. The magnitudes of these shifts reflect the different polarizabilities of the coordinated metal cations. $\mathrm{Mg}^{2+}$ with the largest charge/radius ratio gives the greatest anodic shift and $\mathrm{K}^{+}$the smallest.

In the framework of a study to develop a new class of redox catalytic systems capable of promoting redox reactions on a guest substrate via guest inclusion and Lewis acid catalytic activation, compound 88 was designed containing four benzo-15-crown-5 moieties and eight ferrocenyl redox-active centers. ${ }^{130}$ Reaction of resorcinol and 4-formylbenzo-15-crown-5 (85) under acidic conditions gave resorcin[4]aren $\mathrm{e}^{121} 87$ (Chart 17) which upon treatment with excess of (chlorocarbonyl)ferrocene afforded 88 in $22 \%$ overall yield. Preliminary coordination studies with the sodium cation reveal that one $\mathrm{Na}^{+}$is bound in each of the respective benzo-15crown-5 moieties. Cyclic voltammetric results suggest the ferrocene moieties present in $\mathbf{8 8}$ are oxidized in one step.

\section{Miscellaneous}

The $\left\{\eta^{6}\right.$-phenylmethylsila-14-crown-5\}chromium tricarbonyl complex 89 (Chart 18) was obtained by reacting the corresponding silacrown ether with chromium hexacarbonyl..$^{132}$ Co-complexation of alkali metal cations induced shifts in the ${ }^{13} \mathrm{C}$ NMR absorptions of the $\mathrm{OCH}_{2}$ groups $\left(\mathrm{Li}^{+}, \mathrm{Na}^{+}>\mathrm{K}^{+}\right)$. The corresponding $\left\{\eta^{6}\right.$-phenyldimethoxymethylsila\}chromium tricarbonyl did not show shifts of the $\mathrm{O}^{13} \mathrm{CH}_{2}$ absorptions upon adding alkali metal cations. Cyclic voltammetry in $\mathrm{CH}_{3} \mathrm{CN}$ showed an irreversible oxidation-reduction process (EC mechanism) leading to $\left[\left(\mathrm{CH}_{3} \mathrm{CN}\right)_{3} \mathrm{Cr}\right.$ $\left.(\mathrm{CO})_{3}\right]^{+}$and the silacrown ether. Shifts of the anodic peak up to $110 \mathrm{mV}$ were recorded after adding excess of $\mathrm{MPF}_{6}\left(\mathrm{Li}^{+}>\mathrm{Na}^{+}>\mathrm{K}^{+}\right)$. For the dimethoxy

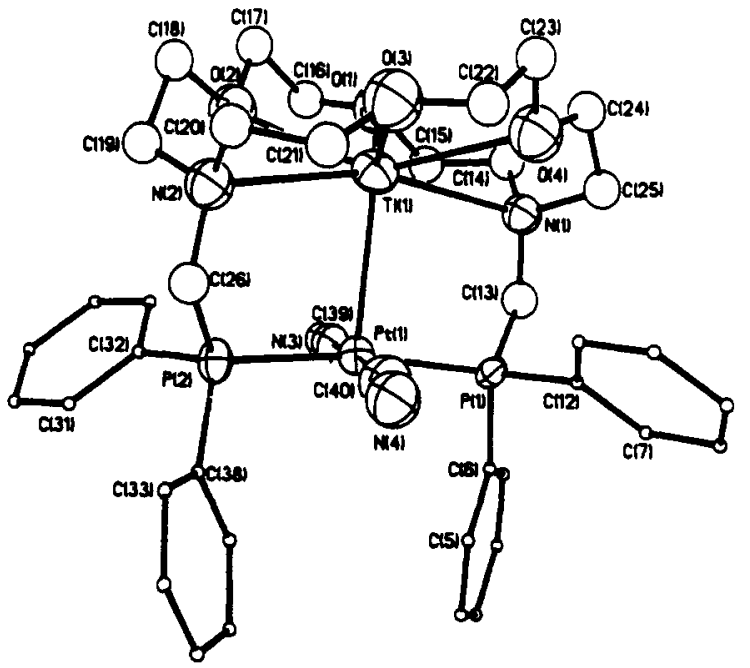

Figure 10. X-ray structure of $92\left(\mathrm{M}_{1}=\mathrm{Pt}, \mathrm{X}=\mathrm{Y}=\mathrm{CN}-\right.$; $\mathrm{M}_{2}=\mathrm{Tl}^{+}$). (Reprinted from ref 135. Copyright 1990 American Chemical Society.)

derivative shifts of $20-25 \mathrm{mV}$ were observed. The mono(chromium tricarbonyl) and bis(chromium tricarbonyl) derivatives of dibenzo-18-crown- 690 have been reported by Pannell et al. ${ }^{133}$ The introduction of the electronwithdrawing chromium tricarbonyl groups decreases the association constants of the complexes with $\mathrm{Na}^{+}$ and $\mathrm{K}^{+}$, as was determined by the picrate extraction method. Unexpectedly, the selectivity of $\mathrm{K}^{+}$over $\mathrm{Na}^{+}$ was reversed for the bis(chromium tricarbonyl) analogue. Yellow chromium tricarbonyl complexes of benzocrown ethers 91 have been obtained by reaction of the benzocrown ethers with chromium hexacarbonyl. ${ }^{134}$ The green NaSCN complex has been reported of (benzo-15-crown-5)chromium tricarbonyl.

Balch et al. ${ }^{135,136}$ synthesized $N, N^{\prime}$-bis $\left(\mathrm{Ph}_{2} \mathrm{PCH}_{2}\right)$ diaza-18-crown-6 starting from diaza-18-crown-6. From this ditopic receptor they prepared a number of heterodinuclear complexes 92, which have a metal-metal bond, except for the potassium/iridium complex. The intermetallic distance determined by $\mathrm{X}$-ray analyses (Figures 10 and 11) are Tl-Ir $2.875 \AA$, Tl-Pt $2.911 \AA$, $\mathrm{Pb}-\mathrm{Ir} 3.12 \AA, \mathrm{Sn}-\mathrm{Ir} 2.92 \AA$, and K-Ir $3.33 \AA$. The

Chart 18

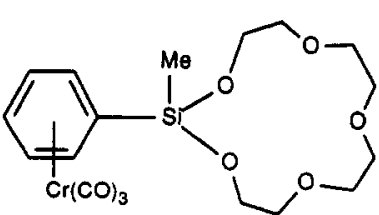

89

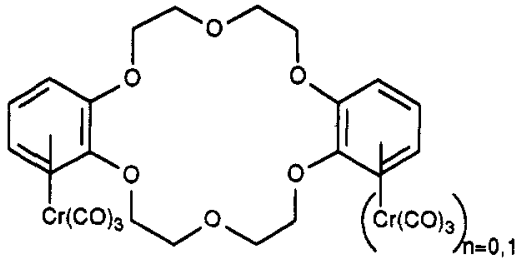

90<smiles>[Y10]CCOCCOc1c2ccc([2H])c1C(C)(C(C)(C)C)OCCOCCOCCO2</smiles>

$\mathrm{R}=\mathrm{H}, \mathrm{Me}$

91
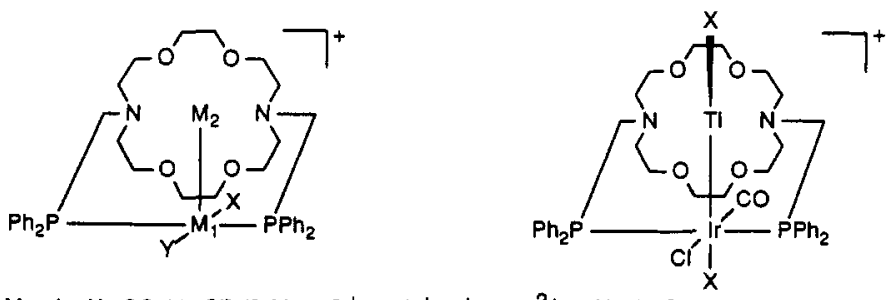

$M_{1}=I r, X=C O, Y=\mathrm{Cl}^{-}, \mathrm{I}^{\prime} ; \mathrm{M}_{2}=\mathrm{TI}^{+}, \mathrm{PbCl}^{+}, \mathrm{K}^{+}, \mathrm{SnCl}^{2+} \quad X=\mathrm{I}^{-}, \mathrm{Cl}^{-}$

$M_{1}=P t, X=Y=C^{*} ; M_{2}=T^{+}$

92 


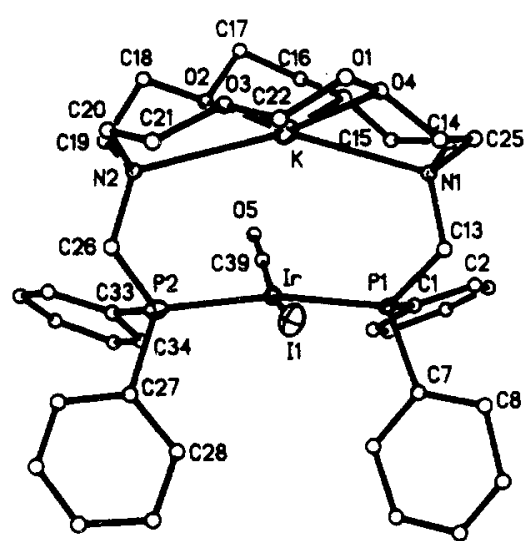

Figure 11. X-ray structure of $92\left(\mathrm{M}_{1}=\mathrm{Ir} ; \mathrm{X}=\mathrm{CO} ; \mathrm{Y}=\mathrm{I}^{-}\right.$; $\mathrm{M}_{2}=\mathrm{K}^{+}$). (Reprinted from ref $136 \mathrm{~b}$. Copyright 1991 American Chemical Society.)

\section{Chart 19}

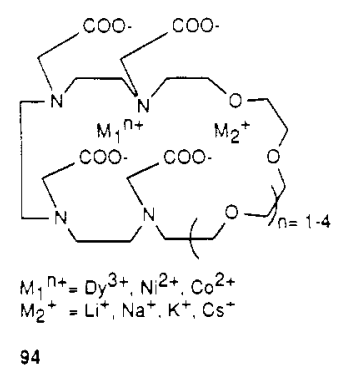

thallium/iridium complex 92 undergoes an oxidative addition with $\mathrm{Cl}_{2}$ or $\mathrm{I}_{2}$ leading to the hetero-dinuclear complex 93 with an X ligand at both apical positions.

The tetraacid precursor for the complexes 94 (Chart 19) was synthesized by reacting the tetraaza-crown ether with $\mathrm{BrCH}_{2} \mathrm{COO}^{-} \mathrm{Na}^{+}$in a mixture of $\mathrm{CH}_{3} \mathrm{CN}$ and water. After complexation of a paramagnetic cation in the tetraacid compartment a shift reagent for hard cations was obtained. The dysprosium complex 94 induced relatively small NMR shifts $(0.18-2.57 \mathrm{ppm})$ of the cocomplexed alkali cations. The authors concluded that it is unlikely that this shift reagent is useful for in vivo NMR studies. ${ }^{137}$

The hetero-tritopic receptors 95a-e (Chart 20) were synthesized by reacting 4 -formylbenzo- 15 -crown- 5 with the appropriate diamine. ${ }^{138-140}$ The corresponding hetero-metallic complexes with $\mathrm{Cu}^{+}$or $\mathrm{Ag}^{+}$and $\mathrm{Na}^{+}$or $\mathrm{K}^{+}$could be isolated. FAB-MS spectrometry and ${ }^{13} \mathrm{C}$ NMR spectroscopy of the copper-containing complexes showed a $\mathrm{Cu}$ to $\mathrm{Na}$ ratio of $1: 2$ and a $\mathrm{Cu}$ to $\mathrm{K}$ ratio of 1:1. The X-ray analysis of $\left[\mathbf{9 5 b} \cdot \mathrm{Cu}^{+} \cdot \mathrm{K}^{+}\right]\left[\mathrm{PF}_{6}\right]_{2}$ showed that the copper is complexed in a distorted tetrahedral geometry with the potassium sandwiched by two crown ether rings. The $\mathrm{Ag}^{+}$-containing complexes showed for both $\mathrm{Na}^{+}$and $\mathrm{K}^{+}$a 1:2 ratio. Sandwiching of $\mathrm{K}^{+}$is not observed possibly due to the larger sterical demand of $\mathrm{Ag}^{+}$compared to $\mathrm{Cu}^{+}$. The tetratopic receptor 96 was obtained by reacting tren with 4-formylbenzo-15-crown5. ${ }^{141}$ The $96 \cdot \mathrm{CuPF}_{6} \cdot\left(\mathrm{NaPF}_{6}\right)_{3}$ complex has been prepared.

The ditopic receptors 97 and 98 (Chart 21) were synthesized by reacting the appropriate monocrown ethers with 3,7-dithia-1,9-nonanedithiol and 3,6-dithia1,8-octanedithiol, respectively. ${ }^{142,143}$ The hetero-dinuclear complex 97. NaSCN.Cu(SCN $)_{2}$ has been reported. The tritopic receptor 99 was obtained by reacting the

\section{Chart 20}
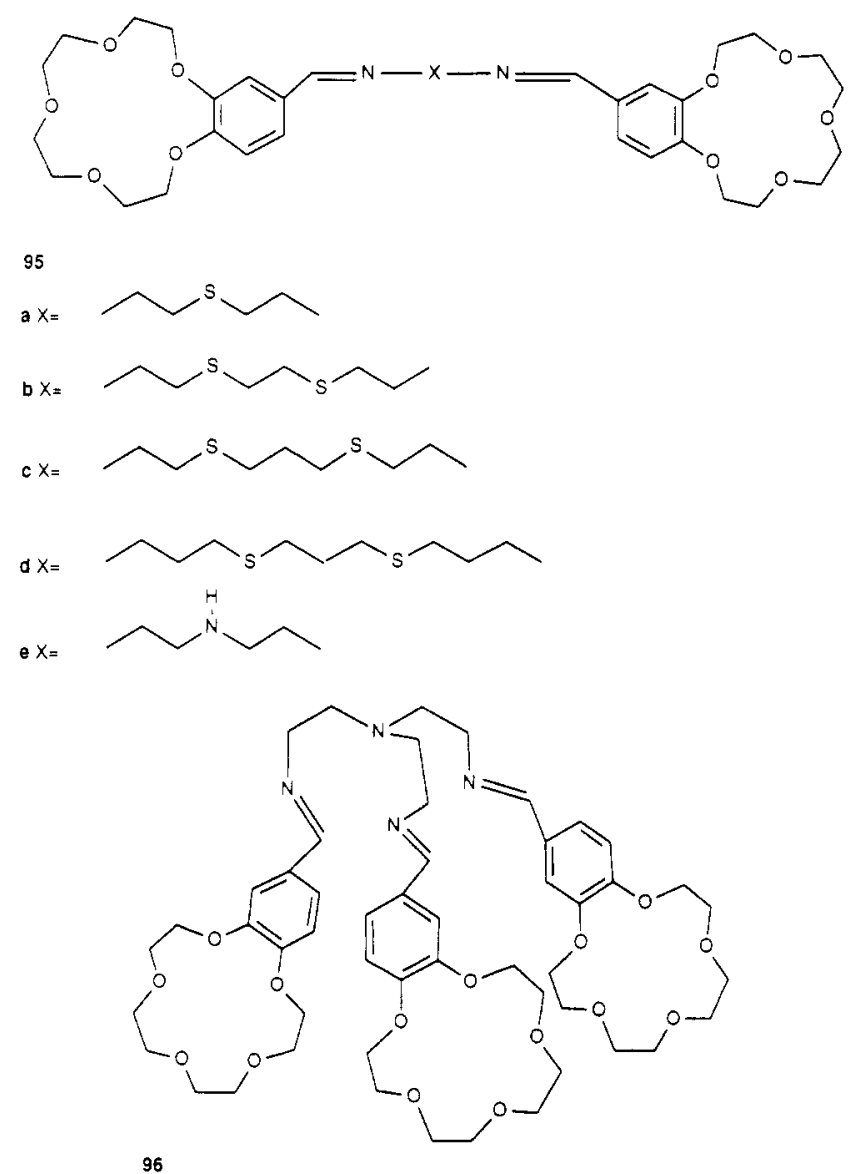

Chart 21

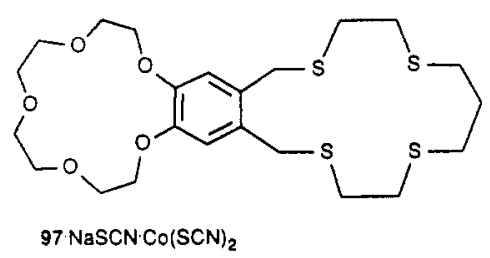<smiles>OCCOCCOCCOCCSCCSCCSCCOCC1(COCCSCCO)COCCOC1</smiles>

98<smiles>OCC1(COCC2=CC=CC3=NCCOCC(COCC4COCCOCCOCCOCCO4)(COCCOCCOCCOCCOCCOC2)COC3)COCCOCCOc2cccc(n2)COC1</smiles>

corresponding monocrown-diol with 2,6-bis(chloromethyl)pyridine under high-dilution conditions in THF. 143,144 The hetero-trinuclear complex 99. $(\mathrm{KSCN})_{2} \cdot \mathrm{Co}(\mathrm{SCN})_{2}$ has been isolated.

Crown ether receptors with di $\left(\eta^{5}\right.$-cyclopentadienyl)tungsten(IV) and -molybdenum(IV) as redox center 


\section{Chart 22}<smiles>CC(C)(C)ON1OCCOCCOCCOCCO1</smiles>

$M=W, M o$

100<smiles>[X]c1ccc2c(c1)OCCOCCOCCOCCOc1ccc([Y])c(c1)OCCOCCOCCOCCO2</smiles>

Chart 23<smiles>O=[N+]([O-])Nc1ccc2c(c1)OCCOCCOCCOCCO2</smiles>

102<smiles></smiles>

103<smiles>O=[N+]([O-])[O+]1CCC2CCC(CO1)C2</smiles>

104<smiles>O=[N+]1C[Nb]2CNc3ccc(c(c3)OCCOCCOCCOCCO2)OCCOCCOCCOCCO1</smiles>

$M 0^{*}=H B\left(3,5-M_{2} C_{3} N_{2} H\right) \cdot M O$

(100 and 101, Chart 22) have been obtained by reacting $\mathrm{Cp}_{2} \mathrm{MCl}_{2}(\mathrm{M}=\mathrm{W}, \mathrm{Mo})$ with the disodium salt of the appropriate dithiol (leading to 100 ), the sodium salt of

\section{Chart 24}

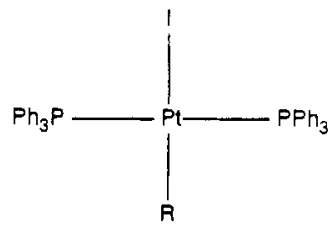

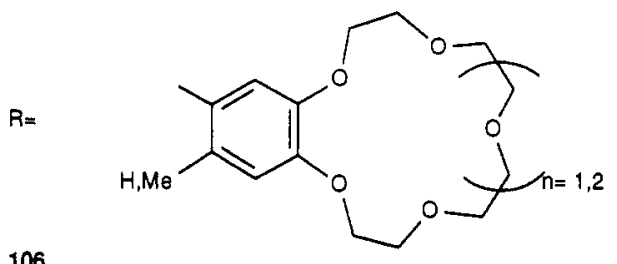

4-thiobenzo-15-crown-5, or the potassium salt of 4-carboxybenzo-15-crown-5 (leading to 101). The reversible one-electron oxidation in $\mathrm{CH}_{3} \mathrm{CN}$ is shifted anodically $\left(50-80 \mathrm{mV}\right.$ ) upon the addition of $\mathrm{Li}^{+}, \mathrm{Na}^{+}$, or $\mathrm{K}^{+}$. The differences between the various alkali metal cations are not large. 145,146

Jones et al. ${ }^{147,148}$ synthesized a number of Mo(III)crown ether complexes (102-105, Chart 23) starting from $\mathrm{Mo}(\mathrm{NO}) \mathrm{LHal}_{2}$ ( $\mathrm{L}=$ tris(3,5-dimethylpyrazolyl)hydroborate) and the appropriate ethylene glycols and amino-substituted benzocrown ethers. They observed electrochemically irreversible reduction/oxidation processes which were shifted anodically up to $320 \mathrm{mV}$ upon co-complexation of $\mathrm{Na}^{+}$or $\mathrm{K}^{+}$.

Oxidative addition of $\mathrm{Pt}$ (stilbene) $\left(\mathrm{PPh}_{3}\right)_{3}$ to 4-iodobenzocrown ethers leads to trans-PtIR $\left(\mathrm{PPh}_{3}\right)_{2}(106$, Chart 24). ${ }^{134}$ Addition of 1 equiv of $\mathrm{NaI}$ did not show significant changes of the chemical shifts but the ${ }^{1} J(\mathrm{Pt}-$ P) coupling constant decreased by $29-35 \mathrm{~Hz}$. Addition of more equivalents of $\mathrm{NaI}$ did not lead to a further decrease indicating a 1:1 stoichiometry of the platium/ sodium complex.

\section{Summary}

It has been shown in this review that complexes with both hard and soft metal cations can be used for bimetallic catalysis and activation, the formation of supramolecular aggregates, allosteric effects, and changing the redox properties of the transition metal cation. The molecular structures used to achieve these goals reflect the variety of approaches used. Although in some cases potential applications have been suggested, until now they have not evolved into prototypes. The authors feel that supramolecular structures with several different metal cations at well-defined places will be the major challenge for the next decade.

\section{References}

(1) Pedersen, C. J. Angew. Chem. 1988, 100, 1053.

(2) Cram, D. J. Angew. Chem. 1988, 100, 1041.

(3) Lehn, J.-M. Angew. Chem. 1988, 100, 91.

(4) For recent books, see: (a) Schneider, H.-J., Dürr, H., Eds. Frontiers in Supramolecular Organic Chemistry and Photochemistry; VCH: Weinheim, 1991. (b) Vögtle, F. Supramolecular Chemistry. An Introduction; Wiley: Chichester, 1991. 
(5) (a) Izatt, R. M.; Pawlak, K.; Bradshaw, J. S. Chem. Rev. 1991, 91, 1721. For recent books, see: (b) Cooper, S. R., Ed. Crown Compounds Toward Future Applications; VCH Publishers, Inc.: New York, 1992. (c) Hiraoka, M., Ed. Crown Ethers and Analogous Compounds, Studies in Organic Chemistry 45; Elsevier: Amsterdam, 1992.

(6) Pearson, R. G. Hard and Soft Acids and Bases; Dowden, Hutchinson, Ross: Stroudsbourg, PA, 1973.

(7) (a) Kimura, K.; Shono, T. Applications of Crown Compounds to Analytical and Separation Chemistry: Ion Sensor and Liquid Chromatography; Chapter 4 in ref 5 c. (b) Cobben, P. L. H. M.; Egberink, R. J. M.; Bomer, J. G.; Bergveld, P.; Verboom, W.; Reinhoudt, D. N. J. Am. Chem. Soc. 1992, 114, 10573.

(8) See, for instance: Dozol, J. F. Use of Liquid Membranes for Treatment of Nuclear Wastes. In Future Industrial Prospects of Membrane Processes; Cecille, L., Toussaint, J.-C., Eds.; Elsevier: London, 1989.

(9) For a recent review, see: Van Straaten-Nijenhuis, W. F.; De Jong, F.; Reinhoudt, D. N. Recl. Trav. Chim. Pays-Bas 1993, 112, 317.

(10) (a) Parker, D. Chem. Soc. Rev. 1990, 19, 271. (b) Parker, D. Tailoring Macrocycles for Medical Applications. Chapter 4 in ref $5 b$.

(11) Patai, S., Rappoport, Z., Eds. Crown Ethers and Analogs; John Wiley \& Sons: Chichester, 1989; Chapter 2.

(12) (a) Yang, X.; Zheng, Z.; Knobler, C. B.; Hawthorne, M. F. J. Am. Chem. Soc. 1993, 115, 193. (b) Rudkevich, D. M.; Stauthamer, W. P. R. V.; Verboom, W.; Engbersen, J. F. J.; Harkema, S.; Reìnhoudt, D. N. J. Am. Chem. Soc. 1992, 114, 9671.

(13) (a) Van Staveren, C. J.; Fenton, D. E.; Reinhoudt, D. N.; Van Eerden, J.; Harkema, S. J. Am. Chem. Soc. 1987, 109, 3456. (b) Van Staveren, C. J.; Van Eerden, J.; Van Veggel, F. C. J. M.; Harkema, S.; Reinhoudt, D. N. J. Am. Chem. Soc. 1988, 110, 4994. (c) Van Doorn, A. R.; Schaafstra, R.; Bos, M.; Harkema, S.; Van Eerden, J.; Verboom, W.; Reinhoudt, D. N. J. Org. Chem. 1991, 56, 6083. (d) Nijenhuis, W. F.; Van Doorn, A. R.; Reichwein, A. M.; De Jong, F.; Reinhoudt, D. N. J. Am. Chem. Soc. 1991, 113, 3607. (e) Van Doorn, A. R.; Verboom, W.; Harkema, S.; Reinhoudt, D. N. Synthesis 1992, 119. (f) Van Doorn, A. R.; Rushton, D. J.; Van Straaten-Nijenhuis, W. F.; Verboom, W.; Reinhoudt, D. N. Recl. Trav. Chim. Pays-Bas 1992, 111, 421. (g) Van Doorn, A. R.; Rushton, D. J.;Bos, M.; Verboom, W.: Reinhoudt, D. N. Recl. Trav. Chim. Pays-Bas 1992, 111, 415. (h) Reinhoudt, D. N.; Van Doorn, A. R.; Verboom, W. J. Coord. Chem. 1992, 27, 91. (i) Reichwein, A. M.; Verboom, W.; Reinhoudt, D. N. Recl. Trav. Chim. Pays-Bas $1993,112,358$.

(14) (a) Maverick, A. W.; Buckingham, S. C.; Yao, Q.; Bradbury, J. R.; Stanley, G. G. J. Am. Chem. Soc. 1986, 108, 7430. (b) Maverick, A. W.; Ivie, M. L.; Waggenspack, J. H.; Fronczek, F. R. Inorg. Chem. $1990,29,2403$

(15) Page, M. J., Williams, A., Eds. Enzyme Mechanisms; The Royal Society of Chemistry: London, 1987.

(16) (a) Latour, J.-M. Bull. Soc. Chim. Fr. 1988, 508. (b) Sorrell, T. N. Tetrahedron 1989, 45, 3. (c) Mahroof-Tahir, M.; Karlin, K. D. J. Am. Chem. Soc. 1992,114,7599, and references cited in there. (d) Bouwman, E.; Driessen, W. L.; Reedijk, J. Coord. Chem. Rev. 1990, $104,143$.

(17) (a) Darensbourg, D. J.; Kudaroski, R. A. Advances in Organometallic Chemistry 22; Academic Press: New York, 1983. (b) Inoue, S.; Koinuma, H. Rev. Inorg. Chem. 1984, 6, 291. (c) Braunstein, P.; Matt, D.; Nobel, D. Chem. Rev. 1988, 88, 747. (d) Behr, A. Angew. Chem., Int.Ed.Engl.1988,27,661. (e) Collin, J.P.; Sauvage, J. P. Coord. Chem. Rev. 1989, 93, 245.

(18) (a) Colquhoun, H. M. Acc. Chem. Res. 1984, 17, 23. (b) Chatt, J. Dilworth, J. R.; Richards, R. L. Chem. Rev. 1978, 78, 589. (c) Leigh, G. J. Acc. Chem. Res. 1992, 25, 177. (d) Shilov, A. E. Pure Appl. Chem. 1992, 64, 1409.

(19) (a) Casellato, U.; Vigato, P. A.; Vidali, M. Coord. Chem. Reu. 1977, 23, 31. (b) Casellato, U.; Vigato, P. A.; Fenton, D. E.; Vidali, M. Chem. Soc. Rev. 1979, 8, 199. (c) Vigato, P. A.; Tamburini, S.; Fenton, D. E. Coord. Chem. Rev. 1990, 106, 25. (d) Guerriero, P.; Vigato, P. A.; Fenton, D. E.; Hellier, P.C. Acta Chem. Scand. 1992, 46,1025 .

(20) Echegoyen, L.; Gustowski,D. A.; Gatto, V. J.; Gokel, G. W. J. Chem Soc., Chem. Commun. 1986, 220, and references cited therein.

(21) Van Staveren, C. J.; Reinhoudt, D. N.; Van Eerden, J.; Harkema, S. J. Chem. Soc., Chem. Commun. 1987, 974.

(22) Van Veggel, F. C. J. M.; Reinhoudt, D. N. Synthetic Metallomacrocycles; Complexes with Neutral Guests and Hetero-di- and Hetero- Trinuclear Complexes. Chapter in ref $4 \mathrm{a}$.

(23) Van Veggel, F. C. J. M.; Harkema, S.; Bos, M.; Verboom, W.; Van Staveren, C. J.; Gerritsma, G. J.; Reinhoudt, D. N. Inorg. Chem. $1989,28,1133$.

(24) Van Veggel, F. C. J. M.; Harkema, S.; Bos, M.; Verboom, W.; Klein Woolthuis, G.; Reinhoudt, D. N. J. Org. Chem. 1989, 54, 2351.

(25) Van Veggel, F. C. J. M.; Bos, M.; Verboom, W.; Reinhoudt, D. N. Recl. Trau. Chim. Pays-Bas 1990, 109, 515.

(26) Van Veggel, F. C. J. M.; Bos, M.; Harkema, S.; Verboom, W.; Reinhoudt, D. N. Angew. Chem., Int. Ed. Engl. 1989, 28, 746.

(27) Van Veggel, F. C. J. M.; Bos, M.; Harkema, S.; Van de Bovenkamp, H.; Verboom, W.; Reedijk, J.; Reinhoudt, D. N. J. Org. Chem. 1991, 56,225 .
(28) Wilkinson, G., Ed. Comprehensive Coordination Chemistry; Pergamon Press: Oxford, 1987.

(29) Sessler, J. L.; Sibert, J. W.; Hugdahl, J. D.; Lynch, V. Inorg. Chem. $1989,28,1417$.

(30) Malhotra, N.; Toftlund, H.; Bojesen, G.; Becher, J. J. Chem. Soc., Chem. Commun. 1989, 1349

(31) Schepartz, A.; McDevitt, J. P. J. Am. Chem. Soc. 1989, 111, 5976.

(32) (a) Holm, R. H.; Everett, G. W., Jr.; Chakravorty, A. Prog. Inorg. Chem. 1966, 7, 83. (b) Holm, R. H.; O'Connor, M. J. Prog. Inorg. Chem. 1971, 14, 841. (c) Yamada, S.; Takeuchi, A. Coord. Chem. Rev. $1982,43,187$.

(33) (a) Schall, O. F.; Robinson, K.; Atwood, J. L.; Gokel, G. W. J. Am. Chem.Soc. 1991, 113, 7434. (b) Schall, O.F.; Robinson, K.; Atwood, J. L.; Gokel, G. W. J. Am. Soc. 1993, 115, 5962.

(34) Fernández-G., J. M.; Rosales-Hoz, M. J.; Rubio-Arroyo, M. F.; Salcedo, R.; Toscano, R. A.; Vela, A. Inorg. Chem. 1987, 26, 349, and references cited in there.

(35) Jones, M. W.; Gupta, N.; Schepartz, A.; Thorp, H. H. Inorg. Chem. $1992,31,1308$

(36) (a) Lindsey, J. S. New. J. Chem. 1991, 15, 153. (b) Whitesides, G. M.; Mathias, J. P.; Seto, C. T. Science 1991, 254, 1312.

(37) Kobuke, Y.; Satoh, Y. J. Am. Chem. Soc. 1992, 114, 789.

(38) Hendriks, R.; Sielcken, O. E.; Drenth, W.; Nolte, R. J. M. J. Chem. Soc., Chem. Commun. 1986, 1464.

(39) Sielcken, O. E.; Van Tilborg, M. M.; Roks, M. F. M.; Hendriks, R.; Drenth, W.; Nolte, R. J. M. J. Am. Chem. Soc. 1987, 109, 4261.

(40) Sielcken, O. E.; Schram, J.; Nolte, R. J. M.; Schoonman, J.; Drenth, W. J. Chem. Soc., Chem. Commun. 1988, 108.

(41) Sielcken, O. E.; Van Lindert, H. C. A.; Drenth, W.; Schoonman, J.; Schram, J.; Nolte, R. J. M. Ber. Bunsen-Ges. Phys. Chem. 1989, 93, 702.

(42) Sielcken, O. E.; Drenth, W.; Nolte, R. J. M. Recl. Trav. Chim. Pays-Bas 1990, 109, 425.

(43) De Jong, F.; Reinhoudt, D. N. Stability and Reactivity of Crown Ether Complexes; Academic Press: New York, 1981.

(44) Gasyna, Z.; Kobayashi, N.; Stillman, M. J. J. Chem. Soc., Dalton Trans. 1989, 2397

(45) Kobayashi, N.; Nishiyama, Y.J.Chem.Soc., Chem.Commun. 1986, 1462 .

(46) Kobayashi, N.; Lever, A. B. P. J. Am. Chem. Soc. 1987, 109, 7433.

(47) Koray, A. R.; Ahsen, V.; Bekâroğlu, Ǒ. J. Chem. Soc., Chem. Commun. 1986, 932.

(48) Ahsen, V.; Yilmazer, E.; Ertas, M.; Bekâroğlu, Ö. J. Chem. Soc., Dalton Trans. 1988, 401.

(49) Sirlin, C.; Bosio, L.; Simon, J.; Ahsen, V.; Yilmazer, E.; Bekâroğlu, Ö. Chem. Phys. Lett. 1987, 139, 362.

(50) Ahsen, V.; Yilmazer, E.; Bekâroǧlu, Ö.; Gül, A.; Bekâroğlu, Ö. Makromol. Chem., Rapid Commun. 1987, 8, 243

(51) Ahsen, V.; Yilmazer, E.; Bekâroğlu, Ö. Makromol. Chem. 1988, $189,2533$.

(52) Musluoğlu, E.; Öztürk, Z. Z.; Ahsen, V.; Gül, A.; Bekâroǧlu, Ö. J. Chem. Res. (S) 1993, 6 .

(53) Sarigül, S; Bekâroğlu, Ô. Chem. Ber. 1989, 122, 291.

(54) Okur, A. I.; Gül, A.; Cihan, A.; Tan, N.; Bekâroğlu, Ö. Synth. React. Inorg. Met.-Org. Chem. 1990, 20, 1399.

(55) Kobayashi, N.; Opallo, M.; Osa, T. Heterocycles 1990, 30, 389.

(56) Kobayashi, N.; Osa, T. Heterocycles 1981, 15, 675.

(57) Bogat-skii, A. V.; Zhilina, Z. I.; Stepanov, D. E. J. Org. Chem. USSR $1982,18,2039$.

(58) Thanabal, V.; Krishnan, V. J. Am. Chem. Soc. 1982, 104, 3643.

(59) Thanabal, V.; Krishnan, V. Inorg. Chem. 1982, 21, 3606.

(60) Maiya, G. B.; Krishnan, V. Inorg. Chem. 1985, 24, 3253.

(61) Chandrashekar, T. K.; Van Willigen, H.; Ebersole, M. H. J. Phys. Chem. 1985, 89, 3453.

(62) Van Willigen, H.; Chandrashekar, T. K. J. Am. Chem. Soc. 1986, $108,709$.

(63) Kruse, R.; Breitmaier, E. Chem. Ber. 1981, 114, 832.

(64) Sakata, K.; Annoura, T. Inorg. Chim. Acta 1990, 176, 123.

(65) Gül, A.; Bekâroğlu, O.. J. Chem. Soc., Dalton Trans. 1983, 2537.

(66) Gül, A.; Okur, A. I.; Cihan, A.; Tan, N.; Bekâroğlu, Ö.J. Chem. Res. (S) 1986, 90.

(67) Ahsen, V.; Gökçeli, F.; Bekâroğlu, Ö. J. Chem. Soc., Dalton Trans. $1987,1827$.

(68) Musluoğlu, E.; Gürek, A.; Ahsen, V.; Tan, N.; Bekâroğlu, Ö. J. Chem. Res. (S) 1990, 146.

(69) Can, S.; Bekêroğlu, O. J. Chem. Soc., Dalton Trans. 1988, 2831.

(70) Thanabal, V.; Krishnan, V. Synth. React. Inorg. Met.-Org. Chem. $1981,11,659$.

(71) Hyde, E. M.; Shaw, B. L.; Shepherd, I. J. Chem. Soc., Dalton Trans. $1978,1696$.

(72) Shaw, B. L.; Shepherd, I. J. Chem. Soc., Dalton Trans. 1979, 1634.

(73) Gök, Y.; Şentürk, H. B. Dyes Pigments 1991, 15, 279.

(74) Sessler, J. L.; Mody, T. D.; Ramasamy, R.; Sherry, A. D. New J. Chem. 1992, 16, 541

(75) Powell, J.; Kuksis, A.; May, C. J.; Nyburg, S. C.; Smith, S. J. J. Am. Chem. Soc. 1981, 103, 5941 .

(76) Powell, J.; NG, K. S.; NG, W. W.; Nyburg, S. C. J. Organomet. Chem. 1983, 243, C1.

(77) Powell, J.; Nyburg, S. C.; Smith, S. J. Inorg. Chim. Acta 1983, 76, L75. 
(78) Powell, J.; Gregg, M.; Kuksis, A.; Meindl, P. J. Am. Chem. Soc. $1983,105,1064$.

(79) Powell, J.; Gregg, M. R.; Kuksis, A.; May, C. J.; Smith, S. J. Organometallics 1989, 8, 2918.

(80) Powell, J.; Kuksis, A.; May, C. J.; Meindl, P. E.; Smith, S. J. Organometallics 1989, 8, 2933.

(81) (a) Powell, J.; Gregg, M. R.; Meindl, P. E. Organometallics 1989 8, 2942. (b) Powell, J.; Lough, A.; Wang, F. Organometallics 1992 11, 2289. (c) Powell, J.; Sawyer, J. F.; Meindl, P. E.; Smith, S. J. Acta Crystallogr. 1990, B46, 753.

(82) McLain, S. J. J. Am. Chem. Soc, 1983, 105, 6355.

(83) McLain, S. J.; Waller, F. J. U.S. Patent 4, 432, 904, 1984; Chem. Abstr. 1984, 100, 210158a.

(84) McLain, S. J. Inorg. Chem. 1986, 25, 3124.

(85) Carroy, A.; Lehn, J.-M. J.Chem. Soc., Chem. Commun. 1986, 1232.

(86) Rebek, J., Jr.; Trend, J. E.; Wattley, R. V.; Chakravorti, S. J. Am. Chem. Soc. 1979, 101, 4333.

(87) Rebek, J., Jr.; Wattley, R. V. J. Am. Chem. Soc. 1980, 102, 4853.

(88) Rebek, J., Jr.; Wattley, R. V. J. Heterocycl. Chem. 1980, 17, 749.

(89) Rebek, J., Jr. Acc. Chem. Res. 1984, 17, 258.

(90) Beer, P. D.; Rothin, A. S. J. Chem. Soc., Chem. Commun. 1988, 52.

(91) Beer, P. D.; Rothin, A. S. Polyhedron 1988, 7, 137.

(92) Beer, P. D. Chem. Soc. Rev. 1989, 18, 409.

(93) Beer, P. D.; Kocian, O.; Mortimer, R. J.; Ridgway, C. J. Chem. Soc., Chem. Commun. 1991, 1460.

(94) Beer, P. D.; Kocian, O.; Mortimer, R. J.; Ridgway, C. Analyst 1992, $117,1247$.

(95) Kocian, O.; Mortimer, R. J.; Beer, P. D. J. Chem. Soc., Perkin Trans. 1 1990, 3203.

(96) Nabeshima, T.; Inaba, T.; Furukawa, N. Tetrahedron Lett. 1987, 28,6211 .

(97) Nabeshima, T.; Inaba, T.; Furukawa, N. Heterocycles 1989, 29, 431.

(98) Nabeshima, T.; Inaba, T.; Furukawa, N.; Ohshima, S.; Hosoya, T.; Yano, Y. Tetrahedron Lett. 1990, 31, 6543

(99) Nabeshima, T.; Inaba, T.; Sagae, T.; Furukawa, N. Tetrahedron Lett. 1990, 31, 3919.

(100) Dürr, H.; Schwartz, R.; Willner, I.; Joselevich, E.; Eichen, Y. J. Chem. Soc., Chem. Commun. 1992, 1338.

(101) Wytko, J. A.; Weiss, J. J. Org. Chem. 1990, 55, 5200.

(102) Wytko, J. A.; Graf, E.; Weiss, J. J. Org. Chem. 1992, 57, 1015.

(103) Ratajczak, A.; Czech, B. Polish J.Chem. 1980, 54, 57 and references cited therein.

(104) Sato, M.; Suzuki, K.; Akabori, S. Bull. Chem. Soc. Jpn. 1986, 59, 3611 and references cited therein

(105) Beer, P. D.; Nation, J. E.; McWhinnie, S. L. W.; Harman, M. E. Hursthouse, M. B.; Ogden, M. I.; White, A. H. J.Chem. Soc., Dalton Trans. 1991, 2485 and references cited therein.

(106) Biernat, J. F.; Wilczewski, T. Tetrahedron 1980, 36, 2521

(107) Akabori, S.; Habata, Y.; Sakamoto, Y.; Sato, M.; Ebine, S. Bull. Chem. Soc. Jpn. 1983, 56, 537.

(108) Akabori, S.; Habata, Y.; Sato, M. Bull. Chem. Soc. Jpn. 1984, 57, 68.

(109) Akabori, S.; Ohtomi, M.; Sato, M.; Ebine, S. Bull. Chem. Soc. Jpn. $1983,56,1455$.

(110) Akabori, S.; Habata, Y.; Sato, M.; Ebine, S. Bull. Chem. Soc. Jpn. $1983,56,1459$.

(111) Akabori, S.; Habata, Y.; Sato, M. Bull. Chem. Soc. Jpn. 1985, 58, 783.

(112) Czech, B.; Ratajczak, A. Polish J. Chem. 1980, 54, 767.

(113) Czech, B.; Ratajczak, A. Chem. Scr. 1981, 18, 195.

(114) Czech, B.; Ratajczak, A.; Nagraba, K. Monatsh. Chem. 1982, 113 965 .
(115) Bellon, P. L.; Demartin, F.; Scatturin, V.; Czech, B. J. Organomet. Chem. 1984, 265, 65 .

(116) Rao, S. J.; Milberg, C. I.; Petter, R. C. Tetrahedron Lett. 1991, 32, 3775 .

(117) Akabori, S.; Fukuda, H.; Habata, Y.; Sato, M.; Ebine, S. Chem. Lett. 1982, 1393.

(118) Izumi, T.; Saitou, K.; Matsunaga, S.; Kasahara, A. Bull. Chem. Soc. Jpn. 1986, 59, 2425.

(119) Czech, B.; Czech, A.; Kang, S. I.; Bartsch, R. A. Chem. Lett. 1984, 37.

(120) Oepen, G.; Vögtle, F. Liebigs Ann. Chem. 1979, 1094.

(121) Izumi, T.; Tezuka, T.; Yusa, S.; Kasahara, A. Bull. Chem. Soc. Jpn. $1984,57,2435$.

(122) Izumi, T.; Murakami, S.; Kasahara, A. Bull. Chem. Soc. Jpn. 1988, 61,3565 .

(123) Bell, A. P.; Hall, C. D. J. Chem. Soc., Chem. Commun. 1980, 163.

(124) Hall, C. D.; Danks, I. P.; Lubienski, M. C.; Sharpe, N. W. J. Organomet. Chem. 1990, 384, 139.

(125) Hall, C. D.; Danks, I. P.; Nyburg, S. C.; Parkins, A. W.; Sharpe, N. W. Organometallics $1990,9,1602$.

(126) Medina, J. C.; Goodnow, T. T.; Bott, S.; Atwood, J. L.; Kaifer, A. E.; Gokel, G. W. J. Chem. Soc., Chem. Commun. 1991, 290

(127) Medina, J. C.; Goodnow, T. T.; Rojas, M. T.; Atwood, J. L.; Lynn, B. C.; Kaifer, A. E.; Gokel, G. W. J. Am. Chem. Soc. 1992, 114, 10583.

(128) Beer, P. D.; Sikanyika, H. Polyhedron 1990, 9, 1091.

(129) Beer, P. D.; Sikanyika, H.; Blackburn, C.; McAleer, J. F.; Drew, M. G. B. J. Chem. Soc., Dalton Trans. 1990, 3295.

(130) Beer, P. D.; Tite, E. L.; Ibbotson, A. J. Chem. Soc., Chem. Commun. 1989,1874

(131) Gutsche, C. D. Calixarenes, monographs in supramolecular chemistry; Stoddart, J. F., Ed.; the Royal Society of Chemistry: Cambridge, 1989; Vol. 1 .

(132) Moran, M.; Casado, C. Ma.; Cuadrado, I.; Losada, J. Inorg. Chim. Acta 1991, 185, 33

(133) Pannell, K. H.; Hambrick, D. C.; Lewandos, G. S. J. Organometal. Chem. 1975, 99, C21.

(134) Odell, K. J.; Hyde, E. M.; Shaw, B. L.; Shepherd, I. J. Organomet. Chem. 1979, 168, 103.

(135) Balch, A. L.; Rowley, S. P. J. Am. Chem. Soc. 1990, 112, 6139.

(136) (a) Balch, A. L.; Neve, F.; Olmstead, M. M. J.Am. Chem. Soc. 1991, 113, 2995. (b) Balch, A. L.; Neve, F.; Olmstead, M. M. Inorg. Chem. $1991,30,3395$

(137) Sink, R. M.; Buster, D. C.; Sherry, A. D. Inorg. Chem. 1990, 29, 3645 .

(138) Beer, P. D. J. Chem. Soc. Chem. Commun. 1986, 1678.

(139) Beer, P. D.; Crane, C. G. Polyhedron 1988, 24, 2649

(140) Beer, P. D.; Crane, C. G.; Drew, M. G. B. J. Chem. Soc., Dalton Trans. 1991, 3235

(141) Beer, P. D.; Crane, C. G.; Tite, E. L. J. Coord. Chem. 1988, 18, 217.

(142) Weber, E.; Skobridis, K.; Ouchi, M.; Hakushi, T.; Inoue, Y. Bull. Chem. Soc. Jpn. 1990, 63, 3670 .

(143) Weber, E. J. Org. Chem. 1982, 47, 3478

(144) Weber, E. Angew. Chem. 1979, 91, 230.

(145) Fu, E.; Green, M. L. H.; Lowe, V. J.; Marder, S. R. J. Organomet. Chem. 1988, 341, C39.

(146) Fu, E.; Granell, J.; Green, M. L. H.; Lowe, V. J.; Marder, S. R.; Saunders, G. C.; Tuddenham, M. J. Organomet. Chem. 1988, 355, 205.

(147) Obaidi, N. A.; Beer, P. D.; Bright, J. P.; Jones, C. J.; McCleverty, J. A.; Salam, S. S. J. Chem. Soc., Chem. Commun. 1986, 239.

(148) Beer, P. D.; Jones, C. J.; McCleverty, J. A.; Salam, S. S. J. Inclusion Phenom. 1987, 5, 521 . 